\title{
On the tectonic origin of Iberian topography
}

\author{
A.M. Casas-Sainz a,?, G. de Vicente b \\ a Departamento de Ciencias de la Tierra, Universidad de Zaragoza, Spain \\ b Grupo de Tectonofísica Aplicada UCM. F.C. Geológicas, Universidad Complutense de Madrid, Spain
}

\section{a rticle info}

\section{Article history:}

Received 28 January 2008

Accepted 26 January 2009

Available online $\mathrm{xxxx}$

\section{Keywords:}

Iberia

Planation surface

Landscape

Meseta

Crustal thickening

Tectonics

\begin{abstract}
a b s t r a c t
The present-day topography of the Iberian peninsula can be considered as the result of the Mesozoic Cenozoic tectonic evolution of the Iberian plate (including rifting and basin formation during the Mesozoic and compression and mountain building processes at the borders and inner part of the plate, during the Tertiary, followed by Neogene rifting on the Mediterranean side) and surface processes acting during the Quaternary. The northern-central part of Iberia (corresponding to the geological units of the Duero Basin, the Iberian Chain, and the Central System) shows a mean elevation close to one thousand meters above sea level in average, some hundreds of meters higher than the southern half of the Iberian plate. This elevated area corresponds to (i) the top of sedimentation in Tertiary terrestrial endorheic sedimentary basins (Paleogene and Neogene) and (ii) planation surfaces developed on Paleozoic and Mesozoic rocks of the mountain chains surrounding the Tertiary sedimentary basins. Both types of surfaces can be found in continuity along the margins of some of the Tertiary basins. The Bouguer anomaly map of the Iberian peninsula indicates negative anomalies related to thickening of the continental crust. Correlations of elevation to crustal thickness and elevation to Bouguer anomalies indicate that the different landscape units within the Iberian plate can be ascribed to different patterns: (1) The negative Bouguer anomaly in the Iberian plate shows a rough correlation with elevation, the most important gravity anomalies being linked to the Iberian Chain. (2) Most part of the so-called Iberian Meseta is linked to intermediate-elevation areas with crustal thickening; this pattern can be applied to the two main intraplate mountain chains (Iberian Chain and Central System) (3) The main mountain chains (Pyrenees and Betics) show a direct correlation between crustal thickness and elevation, with higher elevation/crustal thickness ratio for the Central System vs. the Betics and the Pyrenees. Other features of the lberian topography, namely the longitudinal pro file of the main rivers in the Iberian peninsula and the distribution of present-day endorheic areas, are consistent with the Tertiary tectonic evolution and the change from an endorheic to an exorheic regime during the Late Neogene and the Quaternary. Some of the problems involving the timing and development of the Iberian Meseta can be analysed considering the youngest reference level, constituted by the shallow marine Upper Cretaceous limestones, that indicates strong differences induced by (i) the overall Tertiary and recent compression in the Iberian plate, responsible for differences in elevation of the reference level of more than $6 \mathrm{~km}$ between the mountain chains and the endorheic basins and (ii) the effect of Neogene extension in the Mediterranean margin, responsible for lowering several thousands of meters toward the East and uplift of rift shoulders. A part of the recent uplift within the Iberian plate can be attributed ofi sostatic uplift in zones of crustal thickening.
\end{abstract}

\section{Introduction}

The Iberian topography is characterised by a high average elevation, together with the presence of highly elevated flat surfaces developed all over the Iberian peninsula (the so-called Iberian Meseta). These features de fine a landscape completely different from that of western and Mediterranean Europe and more similar to elevated areas of northern Africa and western Asia ( Birot, 1959; Gladfelter, 1971; Solé Sabarís, 1978, 1983 ). High plains in Iberia can be classi fied according to their geological nature: planation surfaces developed mainly on

? Corresponding author. Tel.: +34 976762072; fax: +34 976761106.

E-mail addresses: acasas@unizar.es (A.M.Casas-Sainz), gdv@geo.ucm.es (G. de Vicente).
Palaeozoic and Mesozoic rocks and sedimentation surfaces of Neogene rocks. Some of the problems involving the timing and development of the Iberian Meseta are here analysed from the geological point of view, considering the role of the overall Tertiary and recent compression in the Iberian plate, the effect of Neogene extension in the Mediterranean margin, the tectonics of the Atlantic margin and the consequences of isostatic uplift in zones of crustal thickening.

The particular topography of the Iberian plate has led to several hypotheses, considering different ages and tectonic origin for the uplift, and attempting to explain the highly elevated central area (the so-called Meseta) of the Iberian microcontinent. The main topographic features of the Iberian Meseta have been previously characterised from geomorphological studies and landscape analysis. Therefore, some of the models 
proposed do not focus on the causes of uplift. Four groups of hypotheses can be established, according to the proposed geometry and origin for the Iberian Meseta: (1) more or less uniform uplift of the Iberian craton after the complete erosion and formation of an Iberian peneplain at the end of the Tertiary (see Vázquez Hoehne, 1992 and references therein),

(2) Tilting of the whole plate towards the west during the Quaternary,

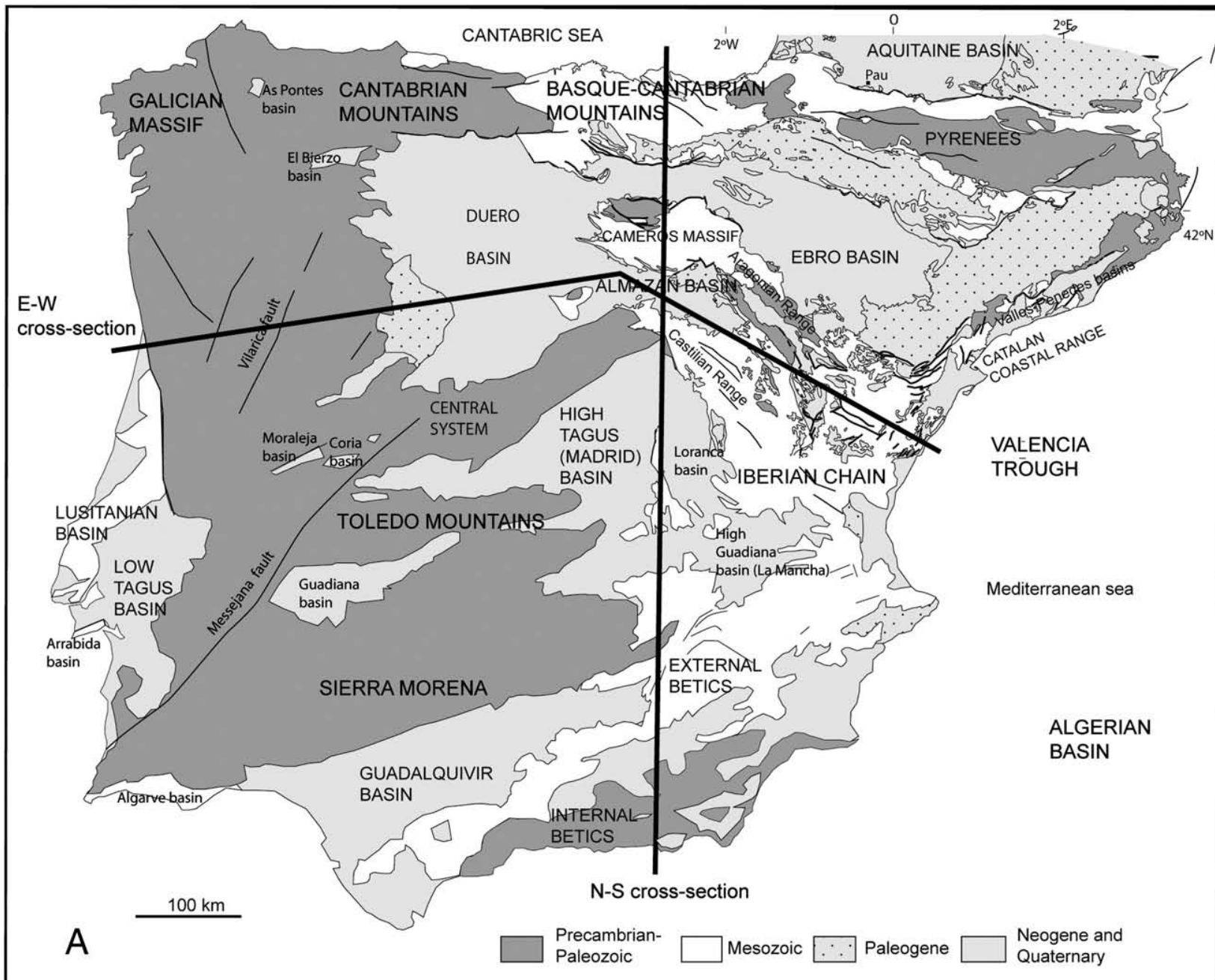

North

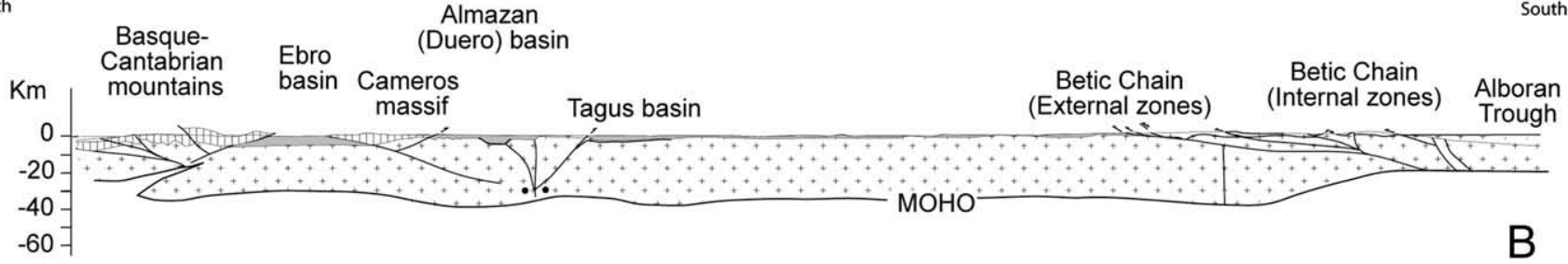

$100 \mathrm{~km}$

WEst

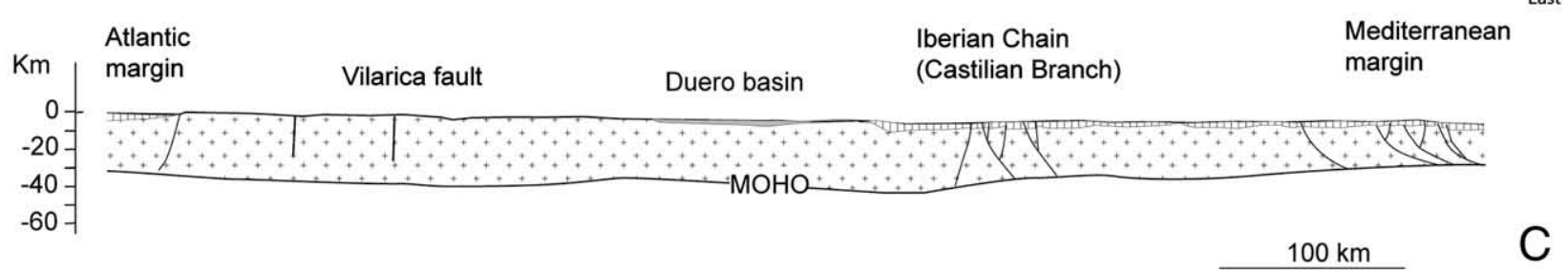

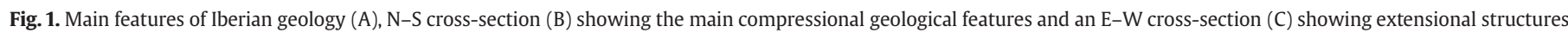
between the Atlantic and Mediterranean continental margins. 
thus conditioning the drainage pattern of the whole Peninsula (see e.g. Solé Sabarís, 1983 and references therein). (3) Dome-shaped structures related to extension in the Mediterranean margin (Simón Gómez, 1984 and references therein). (4) Lithospheric folding, causing the differential uplift of different parts of the Iberian plate and conditioning the distribution of basins and mountains chains, bounded by folds and faults (Cloetingh et al., 2002; De Vicente et al., 2007). Although hypotheses in groups (1) and (2) are related to landscape analyses and do not propose a geological/geophysical approach to the origin of uplift, they must be taken into account when considering analysis of events resulting in distinct landscape evolution and their relative chronology.

The objectives of this paper are: (i) to describe the different types of surfaces that constitute the Iberian Meseta and to propose a classification of surfaces according to the geological background, (ii) to establish a relationship between crustal thickness and topography in the different parts of the Iberian plate, (iii) to define the geological constraints necessary to interpret the Iberian topography in terms of Tertiary/Quaternary uplift and (iv) to discuss the origin of the highly elevated Iberian topography, considering the formation of peneplains and the time in which they reached their present position. We finally interpret Iberian topography in terms of Paleogene structure, recent fracturing, extensional movements, and isostatic rebound. Geological and geophysical constraints are confronted with existing models for the Iberian Meseta.

\section{Geological background}

The topography of the Iberian plate is strongly conditioned by plate tectonic evolution during the Mesozoic and the Tertiary (Casas-Sainz and Faccenna, 2001; Casas and Cortés-Gracia, 2002; Rosenbaum et al., 2002; Cloetingh et al., 2002; Tejero et al., 2006; Vergés and Fernández, 2006; De Vicente et al., 2007). During Mesozoic times, widespread rifting along the eastern, northern and western margins of the Iberian plate, and the eastwards displacement of the Iberian plate with respect to Europe were linked to the opening of the northern Atlantic and rifting in western Europe (Alvaro et al., 1978; Ziegler, 1989, 1990; Salas and Casas, 1993). Since the Late Cretaceous, African-Iberian-Europe convergence and collision (with lithospheric subduction at the southern Iberian margin, Blanco and Spakman, 1993) generated the subsequent uplift of the Pyrenees, the Iberian Chain, the Central System (Casas-Sainz and Faccenna, 2001), and other minor ranges and strike-slip fault corridors (De Vicente and Vegas, 2009-this issue). Thrusting and folding at the plate margins and within the Iberian plate favoured the development of internally drained basins bordering the main mountain chains: the Duero basin in the northern half of the plate, and the high Tagus (Madrid) basin in its southern half (Fig. 1). Conversely, the Aquitaine and Guadalquivir basins, located outside the central part of the Iberian plate (the present-day Iberian Meseta),

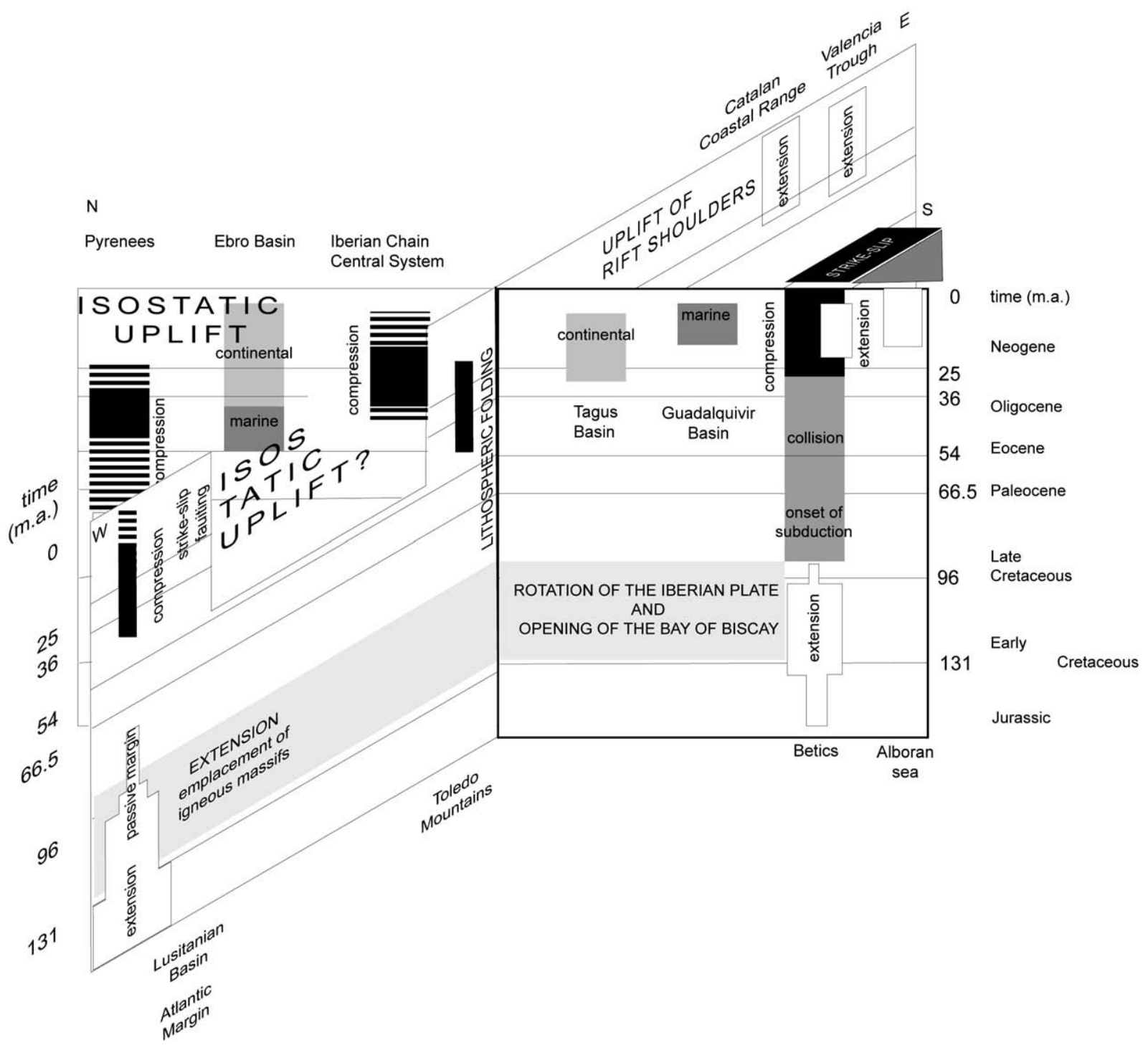

Fig. 2. Sketch showing the main sedimentation and tectonic evolution events across Iberia (N-S and E-W trends) during the Tertiary. 
underwent a marine-continental foreland basin evolution (exorheic), because they were open to the Atlantic ocean since their early evolutionary stage. The Ebro basin underwent a complete evolution from an exorheic foreland basin (turbiditic and molasse) during the Eocene-Early Oligocene, then changing to endorheic during the Late Oligocene and the Miocene (see e.g. Puigdefàbregas, 1975). The changing of drainage type was driven by the uplift of the Pyrenean thrust system at the northern plate boundary.

Extension during the Mesozoic was controlled by rifting (Fig. 1), with several important rift systems: (1) the Basque-Cantabrian-AquitainePyrenean rifting system to the North, mainly controlled by E-W and NW-SE normal faults (Soto et al., 2008 and references therein), (2) the Iberian Basin, in the central-eastern part of the plate (Alvaro et al., 1978; Salas and Casas, 1993; Van Wees et al., 1998), controlled by NE-SW (dominant in the East, Antolín et al., 2008) and NW-SE (dominant in the west, Casas et al., 2000b; Liesa et al., 2000, 2006) faulting, (3) the Betic basins, in the south, separated from the Iberian plate by NE-SW faults (Dewey et al., 1989; Crespo Blanc et al., 1994; Sanz de Galdeano, 1996; Gràcia et al., 2006), (4) the Lusitanian basin, controlled by N-S normal faults delimiting the western Iberian passive margin (Montenat et al., 1988; Pinheiro et al., 1996; Kullberg, 2000). The main rifting stages are Permian-Triassic and Early Cretaceous in age (Sopeña et al., 1983; Salas and Casas, 1993; Van Wees et al., 1998; De Vicente, 2004). These periods are associated with the maximum thickness of syn-extensional deposits within the plate, although important depositional areas, specially linked to the northern plate margin also developed during the Late Cretaceous (Martínez-Peña and Casas-Sainz, 2003; McClay et al., 2004).

The convergence between Africa-Iberia and Europe from the Late Cretaceous onwards brought about the inversion of Mesozoic extensional basins and thick-skin basement uplift zones (Fig. 2). In the central-eastern part of the Iberian peninsula, the Iberian Basin became the Iberian Chain (Alvaro et al., 1978). Folding and thrusting of the Paleozoic basement in areas with no deposition during the Mesozoic (sedimentary highs) were also uplifted, and subsequently formed (i) the Spanish-Portuguese Central System (De Vicente et al., 2007 and references therein) and South of it (ii) the ENE-WSW-oriented mountains chains located between the Central System and the Betic Chain (Toledo Mountains and Sierra Morena, Cloetingh et al., 2002; De Vicente, 2004). The Catalonian Coastal Range, in the East, consists of both basement uplifts in areas with thin sedimentary cover and basin inversion in basinal areas (Guimerà and Alvaro, 1990; Roca and Guimerà, 1992; Roca, 1994). The Mesozoic basins located in the western continental margin were also inverted during this stage (see e.g. Alves et al., 2003). In the northern Iberian margin, the uplift of the Pyrenees consisted of southward-directed basement thrusting together with the inversion of the Cretaceous sedimentary basins (Muñoz, 1992; Teixell, 1998). A consequence of the Pyrenean uplift was the closing of the Duero

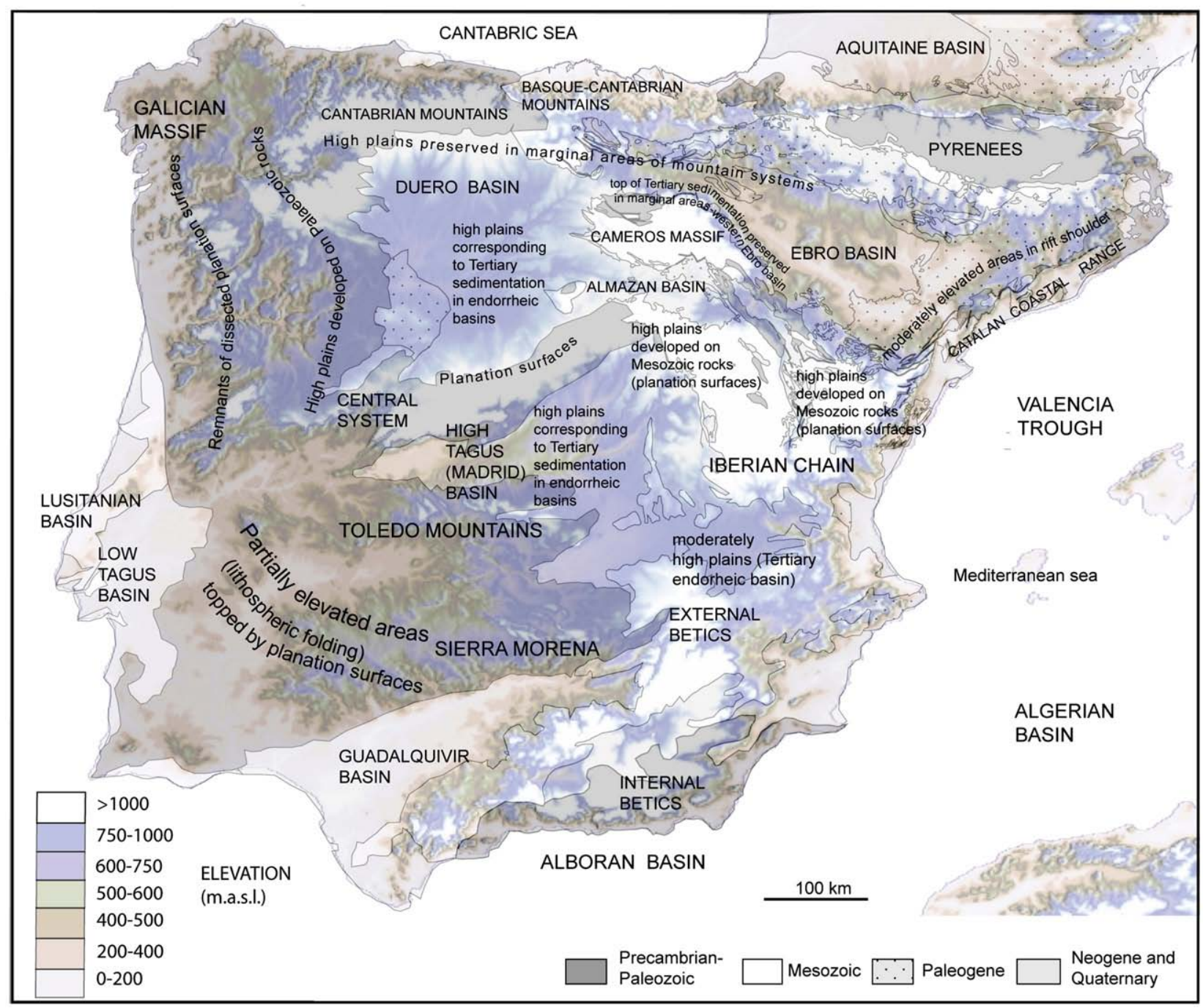

Fig. 3. Comparison between geology and topography in the Iberian peninsula, where the development of high plains in different kinds of rocks can be seen. 
and Ebro basins in its northern edge, thus defining a substantial part of the Iberian Meseta. Southwards, both basins were also closed by the contemporary uplift of the main interior ranges: The Iberian Chain and the Central System.

Extensional movements in the eastern and southern coasts of the Iberian peninsula defined the present-day shape of the continental platform and the oceanic troughs (Roca and Guimerà, 1992; Balanyá et al., 1997). Extension during the Late Paleogene and the Neogene formed the Valencia Trough (continental-intermediate crust, Vegas, 1992) and later on the Alboran Sea and the Algerian basin (Fig. 2), with oceanic crust (Roca, 1994; Sàbat et al., 1995; Sanz de Galdeano, 1996; Balanyá et al., 1997).

The sedimentary filling history of terrestrial basins shows some common features (Calvo et al., 1993; Calvo, 2004) related with tectonic activity in the Iberian plate: (1) The earlier units were deposited during the Eocene, with thick, time-continuous successions, dominated by continental facies with high sedimentation rates. (2) The Duero and Tagus basins begin to individualise since the Late Eocene, indicating the first uplift of the Central System. (3) In contrast with this early, homogeneous stage, during the Oligocene-Early Miocene, the sedimentary filling of the basins was characterised by the formation of discontinuities and/or sedimentary breaks (for definition and use of these terms see e.g. Muñoz-Jiménez and Casas-Sainz, 1998), thus defining several tecto-sedimentary units. Although the number and the specific age of each of these units change from one basin to another, indicating different tectonic activity in the different basin borders, the relevant fact is that the greatest number of sedimentary breaks was concentrated during this period of time, allowing for the whole of these units to be interpreted as syn-tectonic (De Vicente and Vegas, this volume). (4) The final stages in the onshore geological evolution of the Iberian plate are characterised by widespread lacustrine sedimen- tation in the endorheic basins (Miocene, Anadón et al., 1990; Calvo et al., 1993; Alcalá et al., 1994; Anadón and Moissenet, 1996; Alcalá et al., 1997; Alonso-Zarza and Calvo, 2000; Alcalá et al., 2000) and the beginning of capture and exorheism in the Duero, Ebro and Tagus basins (Pliocene and Quaternary, Martín-Serrano, 1991; Gutiérrez et al., 1996; García-Castellanos et al., 2003; Babault et al., 2006). Alluvial deposits were deposited by the fluvial network (Duero, Ebro, Tagus rivers and their tributaries) installed on the ancient internally-drained basins (Gutiérrez et al., 1996).

During the endorheic-exorheic transition, paleo-karstification processes and erosion occurred in the Upper Miocene limestones (Cañaveras et al.,1996). This denudation episode was shortly interrupted by alluvial fan sedimentation during the Late Miocene-Pliocene (forming the Raña deposits) widespread on the Spanish Meseta, immediately before configuration of the Quaternary fluvial network.

\section{Geomorphology}

\subsection{A classification for the high plains in Iberia}

Average elevation of the Iberian peninsula is about $660 \mathrm{~m}$, corresponding to a $3700 \mathrm{~m}$ freeboard of the continental crust over the surrounding oceanic plains. A clear distinction of topography can be established between the northern and southern halves of the plate, both separated by the Central System (Fig. 3). The northern half of Iberia shows an average elevation of $800 \mathrm{~m}$ and its southern half $500 \mathrm{~m}$ (the Betic Chain, for example, shows a mean elevation of about $700 \mathrm{~m}$, Fig. 4). The overall high topography, low relief landscape of the Iberian Meseta is developed in the inner part of the plate, flanked clearly in the north by the Pyrenees-Cantabrian mountains (Fig. 3), and not so clearly in the South by the Betic Chain. Both marginal ranges are

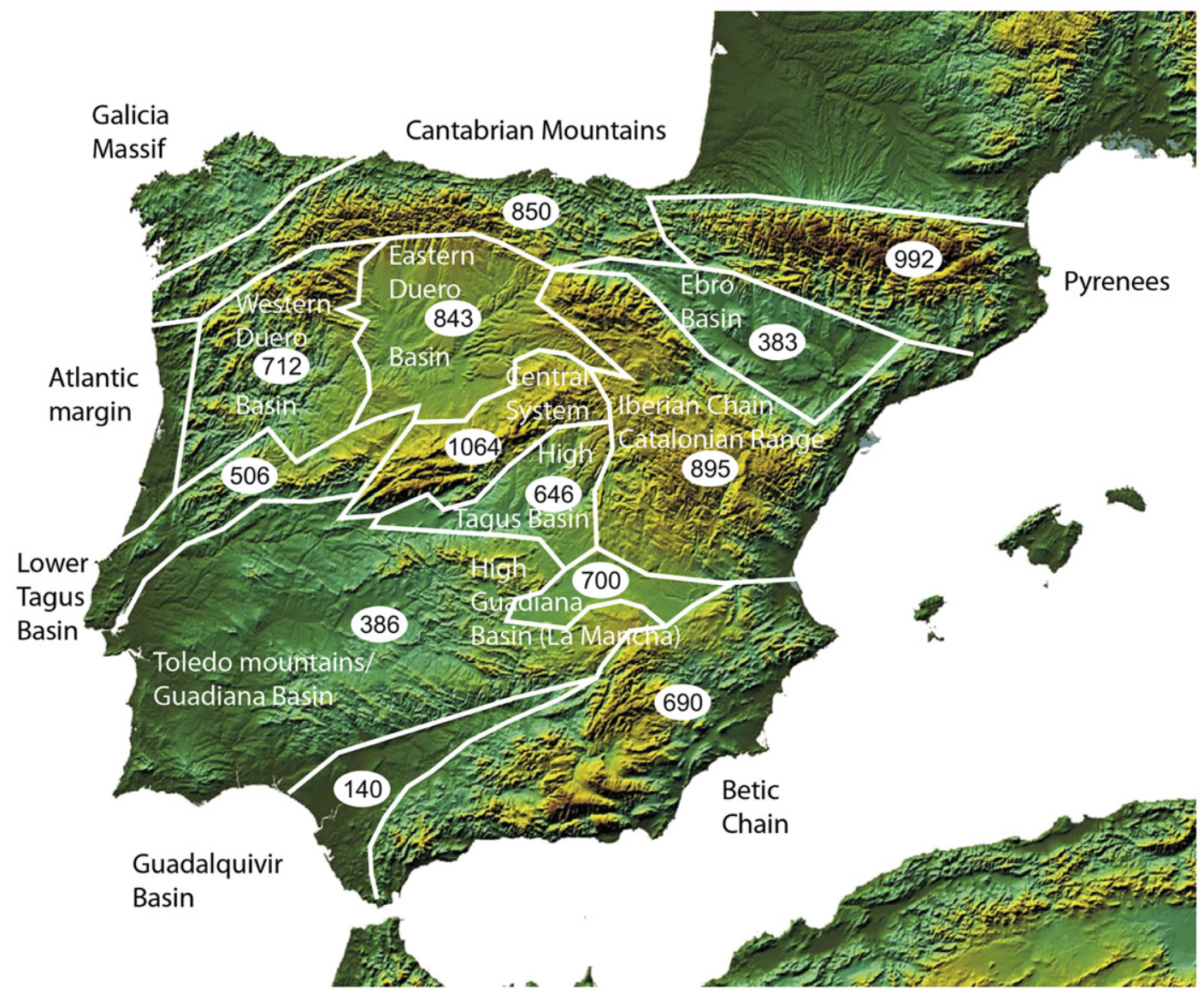

Fig. 4. Topography of the Iberian peninsula showing the main traits of its landscape. Numbers indicate the average elevation of its different sectors. 
thrusting over the Iberian continental plate, what means that in both situations the foreland to the mountain ranges is on the Iberian side.

The Iberian high topography consists mainly of remnants of high plains, dissected by the present-day fluvial network. These remnants of high plains are widespread in the northern half of the Iberian microcontinent, and not so much in its southern half (Figs. 3 and 5). From the geological point of view, two main types of high plains can be distinguished in the Iberian peninsula (Figs. 3 and 5):

- high plains coinciding with Tertiary sedimentary basins (Figs. 3 and 5A), with highest preserved deposits Late Miocene to Pliocene in age and subhorizontal bedding. The main representatives of this kind of surfaces (many of them erosional in their present form) are in the Duero Basin (including the Almazan Basin), at elevations between 700 and $1200 \mathrm{~m}$ a.s.l., and in the Eastern Tagus Basin, at elevations between 500 and $1000 \mathrm{~m}$ a.s.l. (Gracia Prieto et al., 1990; Mediavilla et al., 1996; Gutiérrez Elorza and Gracia, 1997; Alcalá et al., 1997; Cortés, 1999; García-Quintana et al., 2004; Benito-Calvo and Pérez-González, 2007). In the Ebro Basin this kind of surfaces is restricted to marginal areas near the basin margins, since most structural surfaces developed near the central part of the basin are lower than $500 \mathrm{~m}$ a.s.l. and cannot be considered as high plains. Other structural surfaces can reach $800 \mathrm{~m}$ a.s.l. in the basin centre but correspond to levels below the top of Neogene sedimentation (Pérez-Rivarés et al., 2002, 2004).

- high plains consisting of eroded segments of Mesozoic and Palaeozoic rocks with planation surfaces (pediplains), developed on the mountain ranges (fold-and-thrust systems and basement uplifts) formed during the Paleogene-Early Miocene (Figs. 3 and 5B,D,E). This type of surfaces are specially well developed
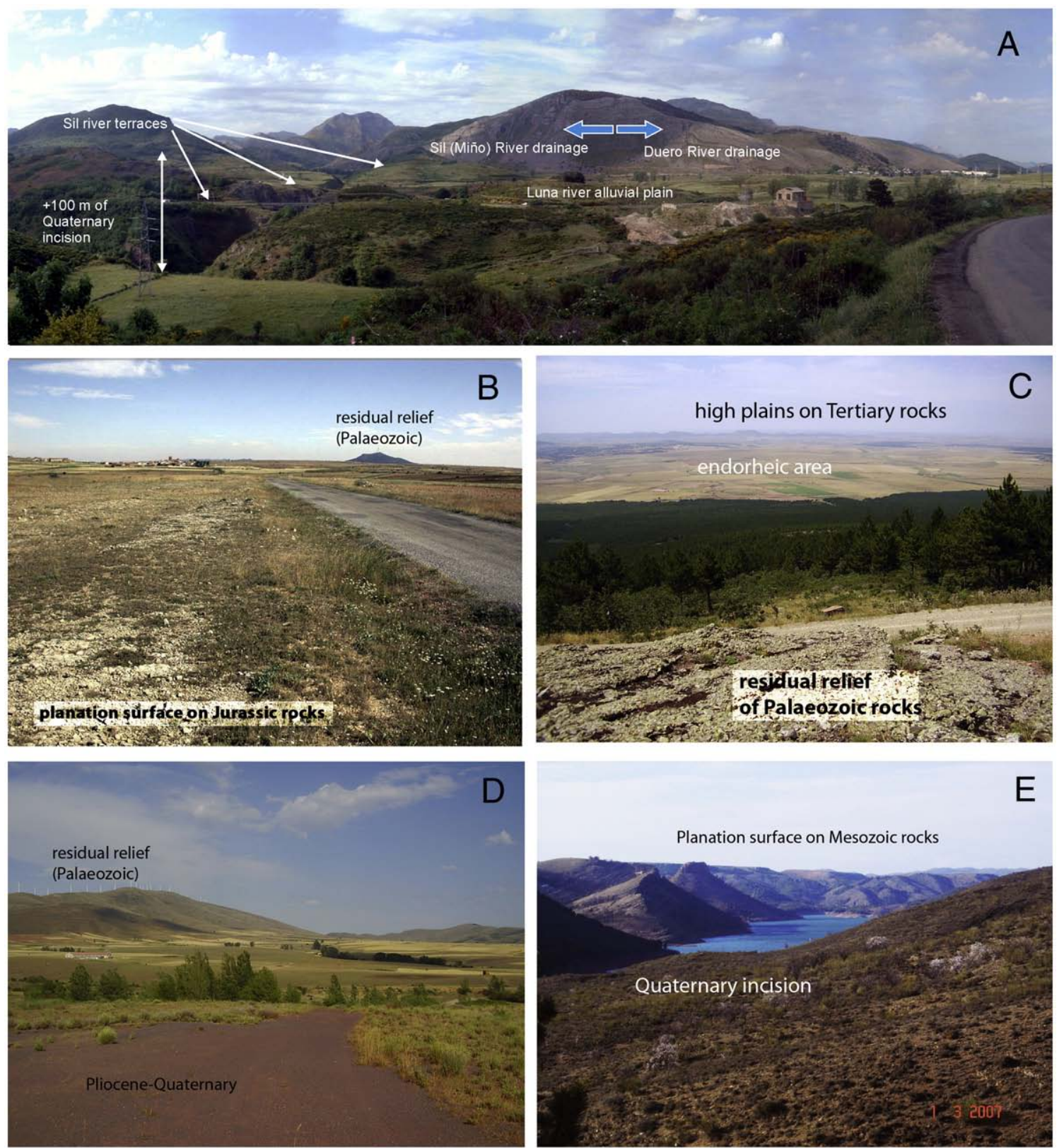

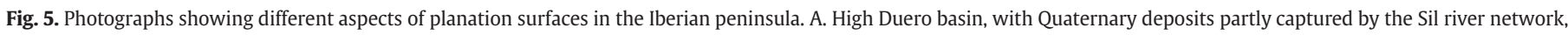

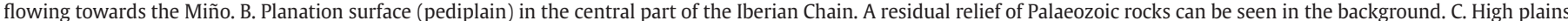

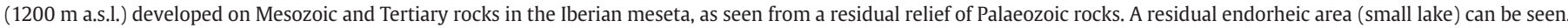

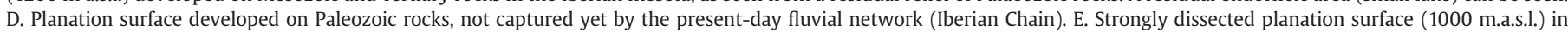
Mesozoic (Triassic, Jurassic, Cretaceous) rocks in the Iberian Chain. 
throughout the Iberian Chain (between 1000 and $1600 \mathrm{~m}$ a.s.l.), the Central System (between 900 and 1500 m. a.s.l.), in marginal areas of the Pyrenees and the Cantabrian mountains (between 1000 and $1300 \mathrm{~m}$ a.s.l.), and finally in the Atlantic margin and the Galician Massif (between 300 and $1700 \mathrm{~m}$ a.s.l, although Quaternary sedimentation surfaces are at lower altitude). In mountain chains, planation surfaces are well preserved close to their borders with the Ebro and Duero basins, and in some areas of the Central System and the Toledo Mountains (Rodríguez Vidal, 1983; Simón Gómez, 1983, 1984; Moissenet, 1985, 1989; Gracia Prieto et al., 1990; Vázquez Hoehne, 1992; Gutiérrez Elorza and Gracia, 1997; Vidal Romaní et al., 1998), and their geometry includes in some areas stepped levels around the highest massifs (Casas and Cortés-Gracia, 2002). Stepped planation surfaces developed in the northwestern corner of the Iberian peninsula (Galician Massif, Fig. 3) linking the summit levels with sea level (as the result of uplift and/or erosional stepping, Vidal Romaní et al., 1998) are the counterpart of erosion surfaces developed on the endorheic face of the mountain chains. On the Atlantic margin the different levels of erosion surfaces are aligned in N-S direction, and have been interpreted as the result of horst-and-graben tectonics involving re-activation of NNE-SSW faults linked to the uplift of the Iberian Meseta during the Neogene and Quaternary (De Brum Ferreira, 1991).

Both types of planation surfaces described can be in continuity at the same elevation and are indistinguishable only from their topographic details (i.e. from topographic maps, Fig. 4, although, for example, karstification is more common on erosional surfaces developed on Mesozoic limestones and structural reliefs or mesas are typical of Neogene basins). The coupled origin of both kinds of surfaces can be related with uplift/sedimentation histories along the Tertiary compressional basin margins in the Iberian peninsula (Guimerà and González, 1998; Casas and Cortés-Gracia, 2002). This can be clearly deduced from some of the geometrical/topographical relationships along the basin borders, for example between the Castilian Branch of the Iberian Chain and the Tagus basin (Fig. 6). In this section the sedimentation surface atop of the Tagus basin can be prolonged northwards to the planation surfaces developed on Mesozoic rocks of the Iberian chain, reaching the topographic Ebro/Duero divide in the Aragonian Branch. Both kinds of planation/ sedimentation surfaces have been strongly dissected since the start of the exorheic drainage, especially in the Ebro and westernmost part of the Tagus Basins (see Figs. 4 and 5A,E). Planation surfaces must be mapped by detailed analysis of contour maps, closely spaced profiles and aerial photographs to ascertain their continuity (Lidmar-Bergström 1988, 1996; Bonow et al., 2006). Correctly mapped they can be used for conclusions on warping, tilting and faulting (Lidmar-Bergström, 1988; De Brum Ferreira, 1991; LidmarBergström, 1996; Casas and Cortés-Gracia, 2002; Bonow et al., 2006). The first type (Neogene top sedimentation surfaces) can be reconstructed when the youngest sediments are partly preserved, what is the case in the heads of the three main Tertiary basins (Ebro, Duero, and Tagus), and taking into account the dip of beds, usually shallowly dipping toward the basin centre. Erosional voids in the Ebro, Duero and Tagus basins can be calculated according to the

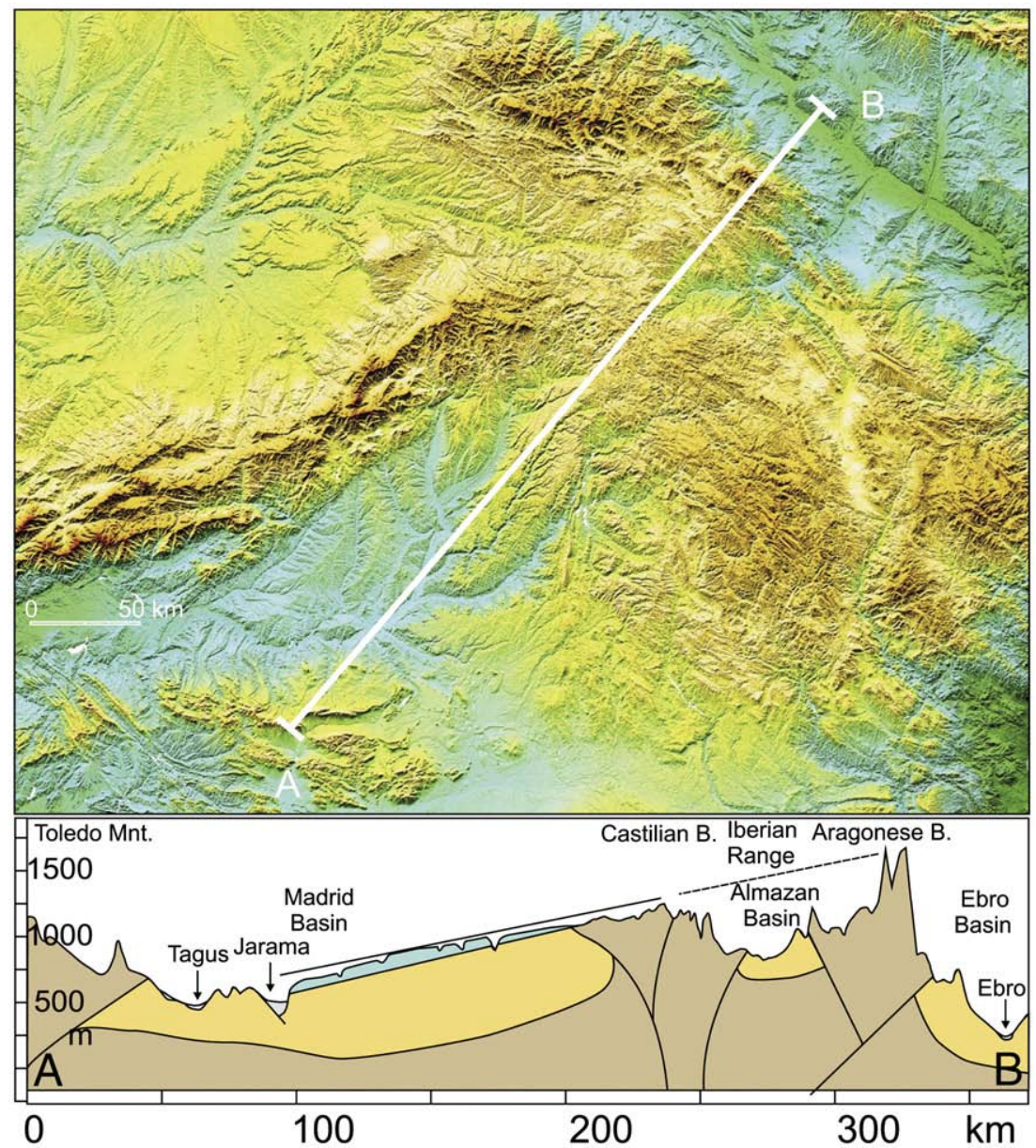

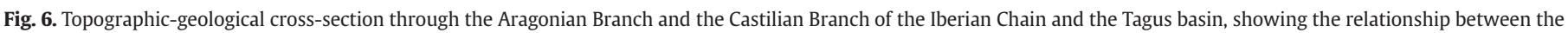
depositional and planation surfaces and their average dip toward the southwest. 
difference between the present-day elevation and the top of sedimentation in the different parts of the basins, and the erosion/ sedimentation balance (Casas et al., 2000b; García-Castellanos et al., 2003).

\subsection{Sedimentation surfaces: reconstruction and dissection}

Although at present most of the alluvial plain of the Ebro River runs below $400 \mathrm{~m}$ a.s.l. (see Fig. 7), before the Quaternary erosional processes the Ebro Basin was at about $1100 \mathrm{~m}$ in elevation (in present-day coordinates), limited to the East by the Catalonian Coastal Ranges. Some areas of the Duero basin record Neogene sedimentation at similar elevations, favouring the interpretation that the different Tertiary basins in north Spain were connected at the end of the endorheic stage (Santisteban et al., 1996; Casas et al., 2000b). Conversely, in contrast with the Ebro Basin, most of the sedimentary plain of the Duero River runs at present between 700 and $1000 \mathrm{~m}$ a.s.l. Erosion in the Ebro Basin progressed from east to west (GarcíaCastellanos et al., 2003), favoured by regressive erosion into the Neogene endorheic basin (Babault et al., 2006). Following this interpretation, the Duero basin is much less eroded than the Ebro Basin, as can also be interpreted from the river profiles (Fig. 7). It could be considered as an earlier stage in the exhumation evolution of the basin, with erosion progressing from the west to the east. This could also indicate a different intensity in the neotectonic activity between the eastern and western parts of Iberia.
In the southern half of the Iberian peninsula the average elevation is lower (Fig. 4), as the Tagus Basin can be divided into two different sectors, separated by a threshold at the confluence between the Central System and the Toledo Mountains: (i) the eastern sector corresponds to a strongly subsiding terrestrial basin (Madrid Basin) that was endorheic during most part of the Cenozoic and was captured only at the end of the Miocene, with a total incision of about $500 \mathrm{~m}$; (ii) the western sector consists of several smaller basins at lower elevations limited downstream by ridges, that were endorheic during some periods of the Cenozoic (Proença Cunha et al., 2005) and were probably open to the Atlantic before the eastern part of the basin was. Both parts of the Tagus basin (eastern and western) were only connected after the installation of the Quaternary fluvial network. South of the Tagus basin, only the upper part of the Guadiana Basin (La Mancha) shows an analogue scenario of high plains linked to endorheic basins at elevations between 600 and 700 m a.s.l. (see Fig. 4).

\subsection{Erosional surfaces}

Flat surfaces are more commonly developed on Mesozoic rocks, mainly Jurassic and Cretaceous marine limestones (Fig. 5B,C,E), with many exo-karstic features. These are usually more frequent the older and higher the planation surface is (Casas and Cortés-Gracia, 2002). Planation surfaces linked to endorheic basins are arranged in stepped levels (between 2000 and $1000 \mathrm{~m}$ in elevation), with different
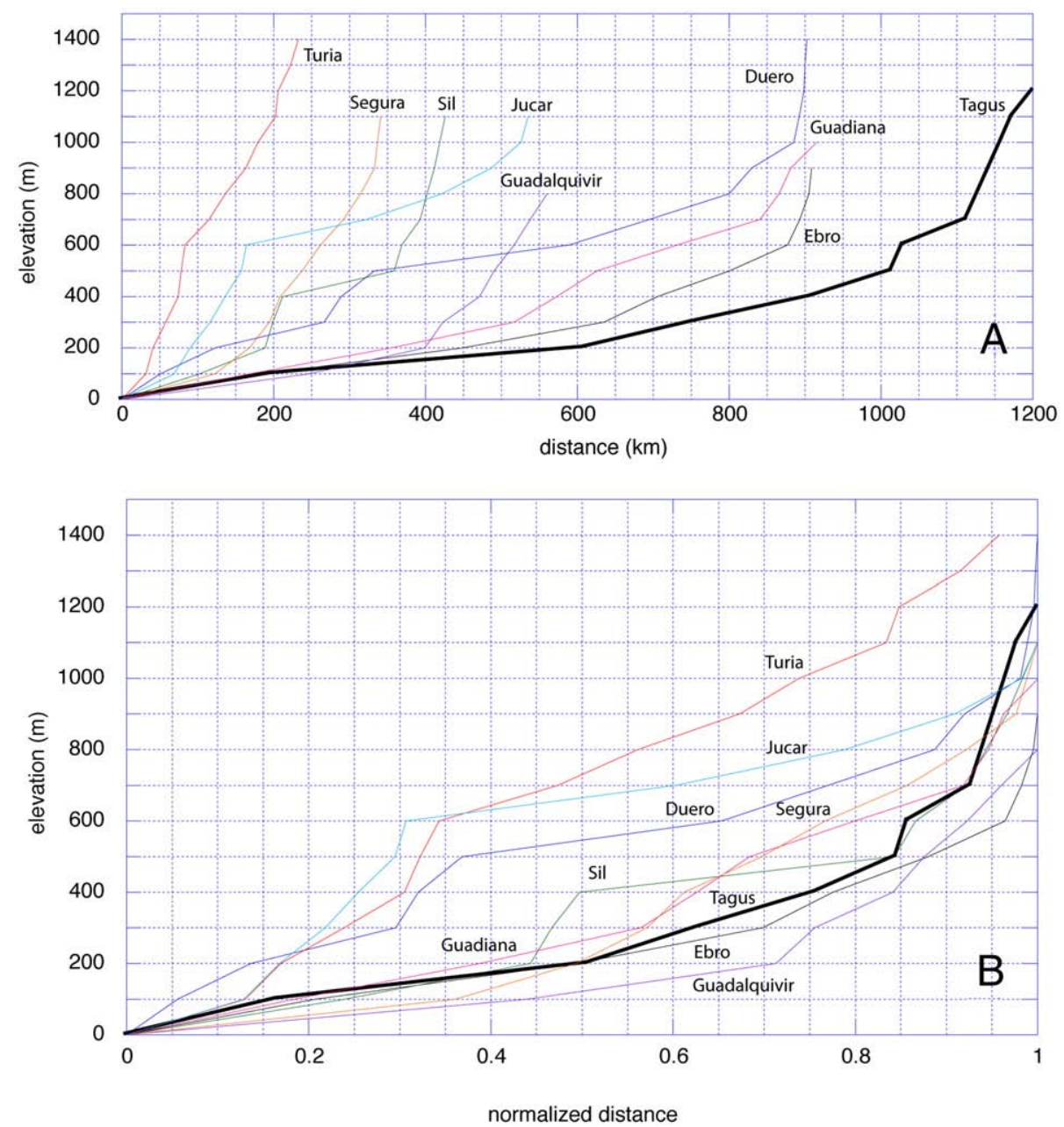

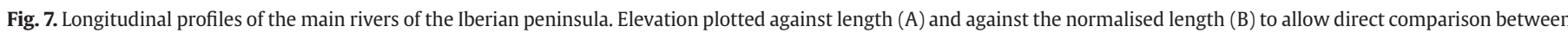
the different rivers. 
degrees of dissection by the Quaternary fluvial network. However, their reconstruction and correlation is still possible in some areas by means of the elevation of the different remnants of planation surfaces (Rodríguez Vidal, 1983; Simón Gómez, 1983, 1984; Gutiérrez Elorza and Gracia, 1997; Gracia et al., 2001, 2002; Casas and Cortés-Gracia, 2002). On the sea-facing side of the mountains the elevation of planation surfaces is usually lower, with recognised remnants down to a few hundred meters above sea-level, allowing for the movement of faults to be reconstructed (De Brum Ferreira, 1991; Vidal Romaní et al., 1998).

Planation surfaces developed on Palaeozoic materials are not so regular as surfaces cutting across the Mesozoic limestones, and usually cover smaller areas, in a similar way to those developed in the Axial Zone of the Pyrenees (cf. Babault et al., 2005). In many places along the Iberian Meseta, Palaeozoic rocks formed residual relief zones standing out on the peneplains (Fig. 5). However, the resistance to linear erosion by rivers during the exorheic stage was probably lower in the Paleozoic rocks, specially in fractured zones, than in the Mesozoic rocks, favouring linear incision along the main Variscan structural trends (NW-SE in the eastern part of northern Iberia, see Fig. 12, NE-SW in the Duero Basin and the Central System, Alvaro et al., 1978; Cortés et al., 2003).

\section{Constraints on rock uplift}

\subsection{Geological constraints: elevation of geological markers}

The maximum uplift or subsidence of surfaces or rocks (for a discussion of terms such us surface uplift, uplift of rocks and exhumation we follow here the terminology established by England and Molnar, 1990, see also De Bruijne and Andriessen, 2002) can be constrained by means of geological markers, provided that such features have known elevation at their formation time and were flat in origin. In any case, it must be taken into account that the accuracy in the detection of subsidence/uplift will be lower than the original topographic irregularities of the chosen surface combined with the uncertainties in the determination of its original elevation. Both planation and sedimentation surfaces may fit these conditions. However, since planation surfaces can form at any height within a mountain range (as demonstrated by Babault et al., 2005, 2007), and they can be reworked along long time spans (Casas and Cortés-Gracia, 2002), their use as uplift indicators can be problematical, even if their age, in the case of the Iberian Peninsula, can be roughly constrained between the Late Eocene and the Pliocene.

Surfaces older than the Neogene can offer a good reference, especially when a sedimentary cover of known age is overlying them. The main drawback of ancient surfaces is that their present-day geometry is the result of cumulated events and that interpretation must be done carefully in order to filter the topographic changes derived from recent movements. In our opinion, two main geological markers can be used to constrain the geological history of Iberian topography (Fig. 8):

- Since the Upper Cretaceous consists of shallow marine limestones, widespread throughout the Iberian plate (and much of western Europe), the top of this sedimentary unit gives a reliable indicator predating Tertiary deformation. The drawbacks for using this surface are mainly related to (i) erosion of Upper Cretaceous levels in many areas that only allow for minimum values for its elevation, and therefore for uplift to be given for these areas, and (ii) the long time span between the Late Cretaceous and the Quaternary, that only allows for a time-limit frame for the values given by other chronological techniques to be obtained, but not for precising movements from 60 m.a. onwards.
- The elevation of the top of the Paleozoic. The topography of this surface is the result of the Mesozoic extensional movements, the Tertiary compression and the recent movements. In spite of its complex history, its elevation can give some clues to reject models non-consistent with its long-wavelengths undulations. It also allows for depicting deformational features in areas (western part of Iberia) where the Upper Cretaceous is deeply eroded.

The elevation of the top of the Palaeozoic basement (Fig. 8B) reflects basin evolution during the Mesozoic (overall lowering form West to East), and compressional uplift of the main chains during the Tertiary (see e.g. Soto et al., 2006): linear E-W trend in the Pyrenees, the Central System, and the Betic Chain, NW-SE trend in the Iberian Chain, NE-SW trends in the Central System and the Catalonian Coastal Range and NNE-SSW in the Vilariça left-lateral Fault System. The main lows of this surface are located in intraplate continental basins (Tagus, Duero and Ebro basins) where it reaches more than 4000 m below sea level (De Vicente et al., 1996; Muñoz-Jiménez and Casas-Sainz, 1998; Casas et al., 2000b). Calculations considering local isostatic equilibrium (Casas et al., 2000b) indicate a contribution of both filling of intra-mountain troughs bounded by folds and thrusts and local isostatic compensation due to the filling of these troughs.

Elevation of the top of the Upper Cretaceous (a flat surface at sea level before the Tertiary compressional-extensional processes, Fig. 8A) gives a clue for the uplift/subsidence of all the eastern part of Iberia, where this surface is preserved, or can be reconstructed reliably. The maximum amount of uplift since Late Cretaceous times is given by this surface, what can help to contrast some of the hypotheses proposed for the evolution of eastern Iberia. In areas eroded below this level (top of the Upper Cretaceous), a minimum amount of uplift can be obtained, although in the western third of the Iberian peninsula the paleo-elevation of the basement during the Late Cretaceous is not known and therefore uplifts calculated by this method can be overestimated.

The contours of the Upper Cretaceous surface are also a good indicator of the eroded volume of rocks in the different mountain ranges. Some crests in the Iberian Chain are eroded up to $1400 \mathrm{~m}$ whereas the average erosion above the present day topography in this chain is $580 \mathrm{~m}$ (Casas and Cortés-Gracia, 2002). In the marginal areas of the Central System and the Cantabrian mountains the geometry of the Upper Cretaceous can also be reconstructed, but its position above the present-day outcrops in the central part of these chains is more speculative, with minimum uplift values higher than $2000 \mathrm{~m}$ (see, e.g., De Vicente et al., 1996; Alonso et al., 1996; Alonso and Pulgar, 2004; De Vicente et al., 2007). Although this can only be considered as a minimum value, taking into account the thin-skinned compressional deformation in these areas, the upper limit for the top of the Upper Cretaceous is probably not much beyond this figure (see abovetopography reconstructions by Alonso et al., 1996; De Vicente et al., 1996).

From the reconstruction of the top of the Upper Cretaceous both in the mountain chains and the Tertiary basins, minimum tectonic topographies of $7000 \mathrm{~m}$ for the borders of basins can be established, with a time span for their formation extending from the Eocene to present-day. This implies a strong component of compressional tectonics in the present-day topography that should be taken into account when considering models for the recent evolution of the Iberian plate.

\subsection{Geophysical data: crustal thickness vs. topographic elevation}

Crustal thickness in the Iberian peninsula can be constrained mainly from gravimetric data (De Vicente, 2004), although some seismic refraction profiles can help to constrain gravimetric models (Zeyen et al., 
A

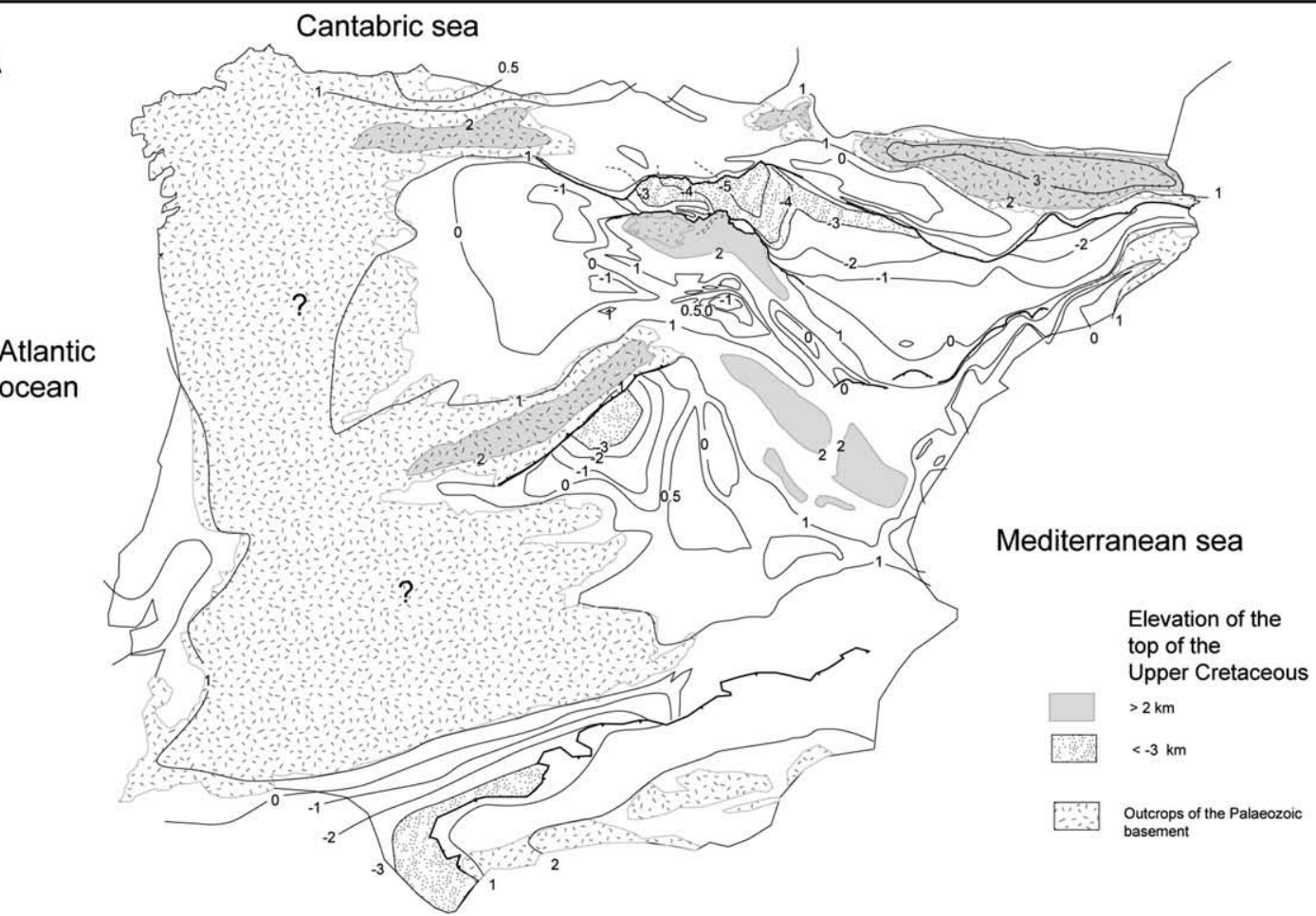

B

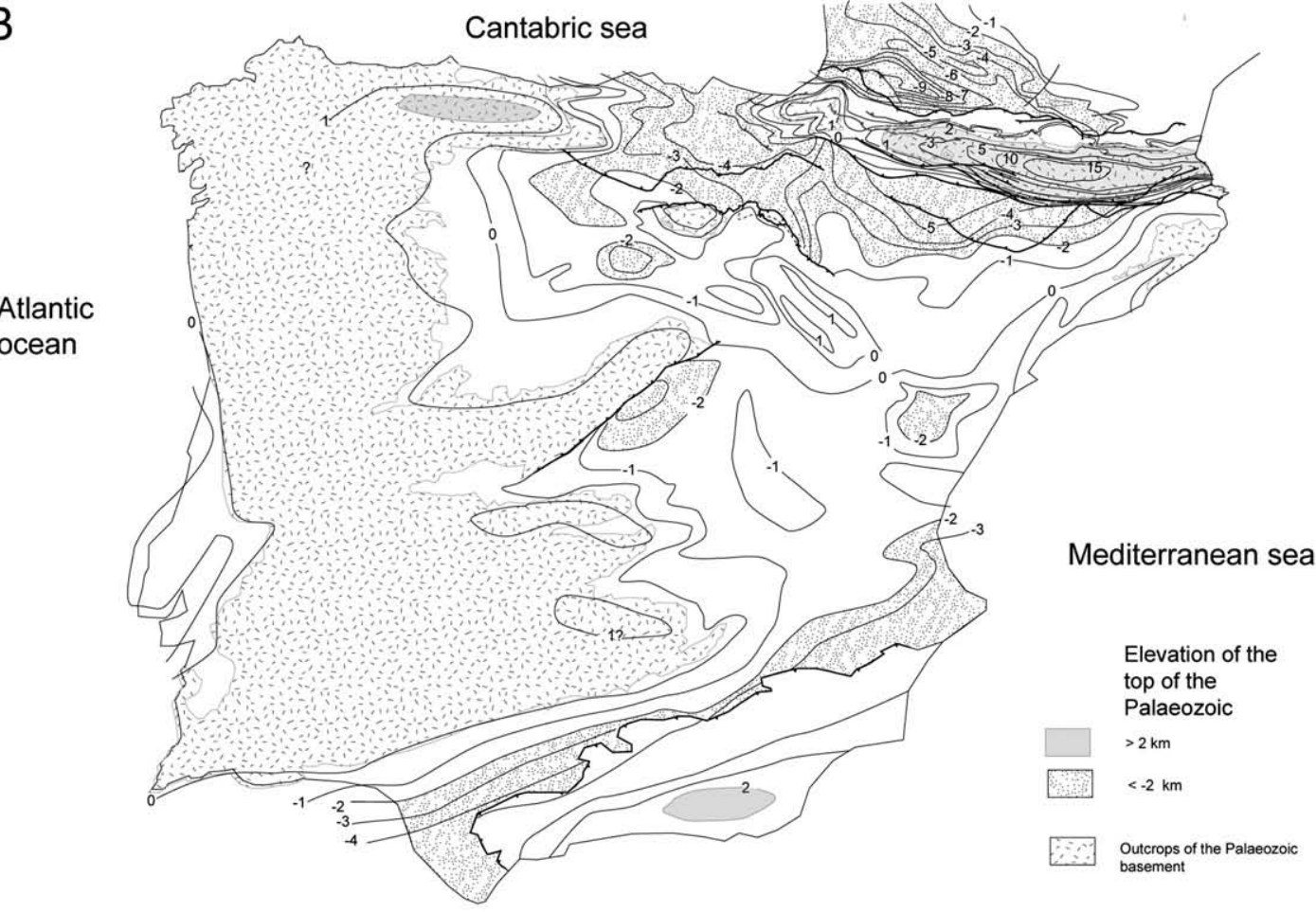

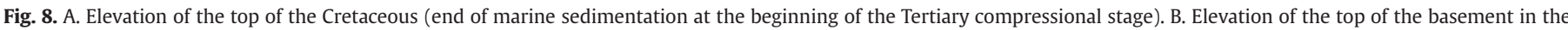

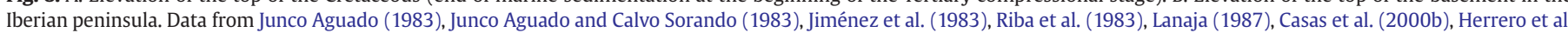
(2004), Soto et al. (2006).

1985; Tesauro et al., 2007). In general, the Bouguer anomaly clearly defines the contour of the Iberian microcontinent, with sharply decreasing values toward the eastern, northern and western coastal lines (Fig. 9, Mezcua et al., 1996; De Vicente, 2004). The above-described asymmetry in the elevation of the Iberian peninsula is also reflected in the Bouguer anomaly map (De Vicente, 2004), with more important negative anomalies (except for the Betic Chain) in the northern part of the plate. Crustal thickness maxima follow more or less the trends of the main mountain chains (De Vicente, 2004): (i) Cantabrian Mountains and Pyrenees, with crustal roots of more than $45 \mathrm{~km}$, separated from each 


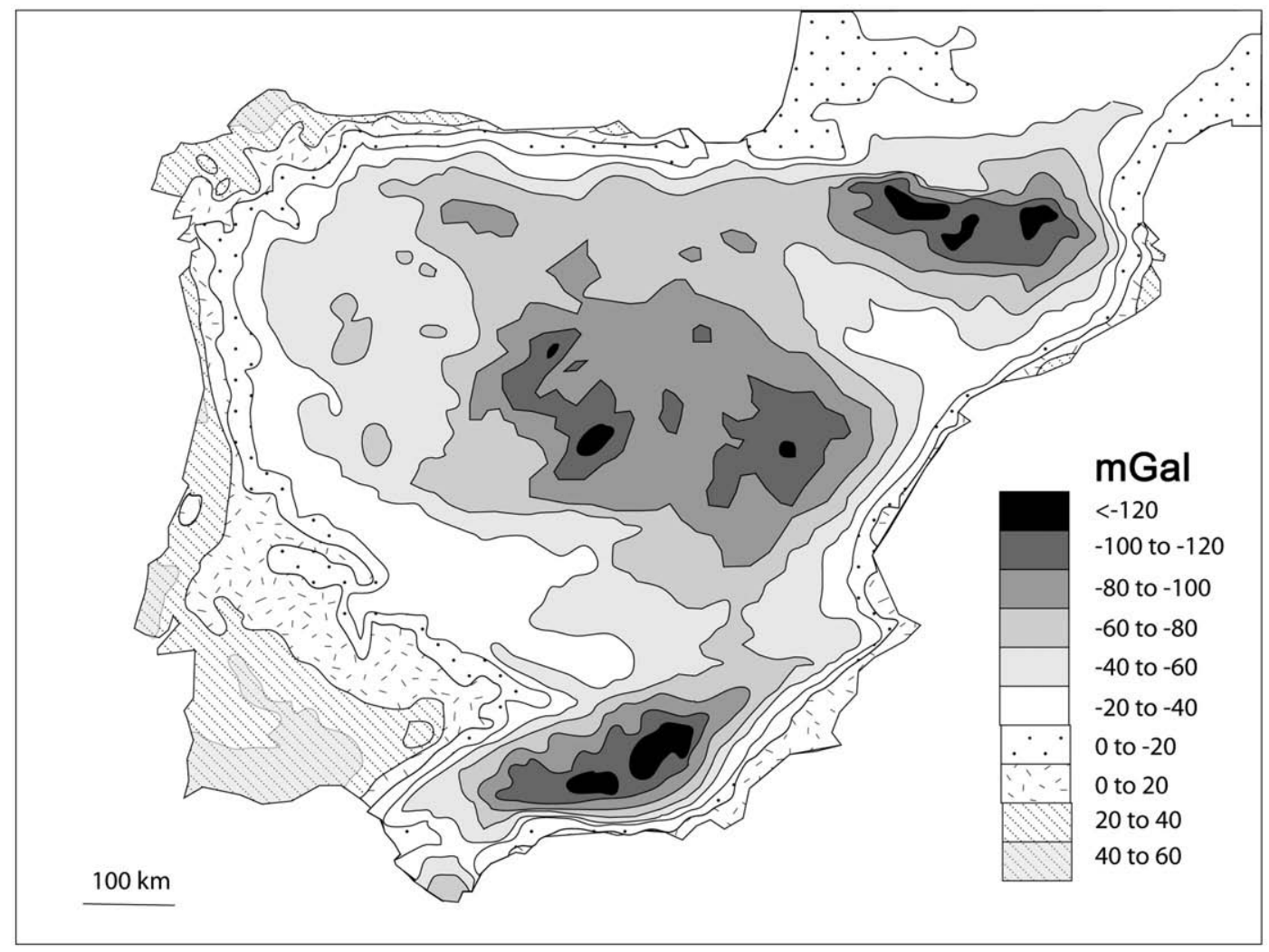

Fig. 9. Bouguer anomaly map of the Iberian peninsula. Modified from De Vicente (2004).

other by lower crustal thickness below the Basque-Cantabrian mountains (resulting from the inversion of the Mesozoic BasqueCantabrian basin), where strong extensional movements took place during the Cretaceous stretching stage (see e.g. Pujalte, 1982, 1989; García-Mondéjar et al., 1996; Soto et al., 2008). Toward the west, this crustal thickness maximum describes an NW-facing arc-shaped toward the northwestern corner of Iberia, adopting there a NNE-SSW trend that mimics the Vilariça Fault System, with similar crustal thicknesses; (ii) The Central System, with a NE-SW elongated maximum, more pronounced in the East, near the maximum thickness of sediments in the high Tagus basin (Madrid basin), and progressively diminishing toward the West, becoming unnoticeable near the Portuguese coastline; (iii) The Bouguer anomaly in the Iberian Chain is not so clearly defined, probably because of the previous extensional history of this massif during the Mesozoic that produced a wide area with extensional deformation, instead of rectilinear grabens (Guimerà et al., 1996). The Iberian Chain, together with the Central System, defines a compact rectangle-shaped positive Bouguer anomaly in the northern-central part of Iberia, between the northern plate margin and the Tagus Basin. The Catalonian Coastal Range, located towards the shoreline, does not show a well-defined gravimetric anomaly, because of its proximity to the positive areas of the Mediterranean marine platform; (iv) the Betic Chain, with a strong anomaly parallel to the coastline continues to the South with the important positive anomaly corresponding to the Alboran Trough and (v) the mountain segments south of the Central System, where the gravimetric anomaly is strongly conditioned by a NW-SE lineament south of the Central System, coinciding with the limit between areas with thick Mesozoic cover and Tertiary compressional deformation consisting of well-defined thrusts and foreland basins to the NE (Iberian Chain, Central System) and the area without Mesozoic cover and moderate thick-skin basement uplifts (Toledo Mountains). Furthermore, this lineament can also be related to a Pliocene volcanic area (Campos de Calatrava) and it represents a limit for instrumental seismicity at present.
Several models regarding the high topography of the Iberian Meseta have been defined, considering both extensional and compressional origins (see, e.g. Simón Gómez, 1983, 1984, 1986, 1989; Gutiérrez Elorza and Gracia, 1997; González et al., 1998; Gracia et al., 2001, 2002; Casas and Cortés-Gracia, 2002; Gutiérrez et al., 2008). A possibility to distinguish between the two end-member models is the correlation between crustal thickness and topographic elevation (Fig. 10). High continental areas with crustal roots are probably related with thickening under a convergence regime, whereas elevated areas related to crustal thinning can be linked to extensional processes (mainly rifting). Intermediate models can be associated with lithospheric folding (Cloetingh et al., 2006).

The relationship between topographic elevation and crustal thickness or Bouguer anomaly (Fig. 10) allows for the different geological areas to be differentiated according to their geophysical signature. In the Iberian peninsula (Fig. 10), elevated zones within the northern part of the plate coincide with areas of maximum crustal thickness and a decrease (more negative) in the Bouguer anomaly, especially in the Cantabrian mountains, the Pyrenees (western zone) and the Central System, where no important extensional movements took place during Mesozoic times. In the three main mountain ranges (Pyrenees, Betics and Central System) there is a rough exponential relationship between both parameters, the Central System showing higher elevations for similar crustal thicknesses than the Betics (intermediate relationship) and the Pyrenees (minimum elevation/ thickness ratio). The Iberian Chain is also characterised by a thick crust, with a thicker crust in relation to the topographic elevation than other areas in the Iberian mainland. It is important to note the relative disagreement existing between Moho depth and Bouguer anomaly for the Iberian Chain. The flat areas corresponding to the Iberian Meseta (Duero Basin, Iberian Chain) fit within the intermediate elevation and Moho depth between 30 and $40 \mathrm{~km}$ zone, relatively well individualised in diagrams shown in Fig. 10A,B. In general, in all the extensive elevated areas, except for the southwestern part of Iberia, there is a direct 

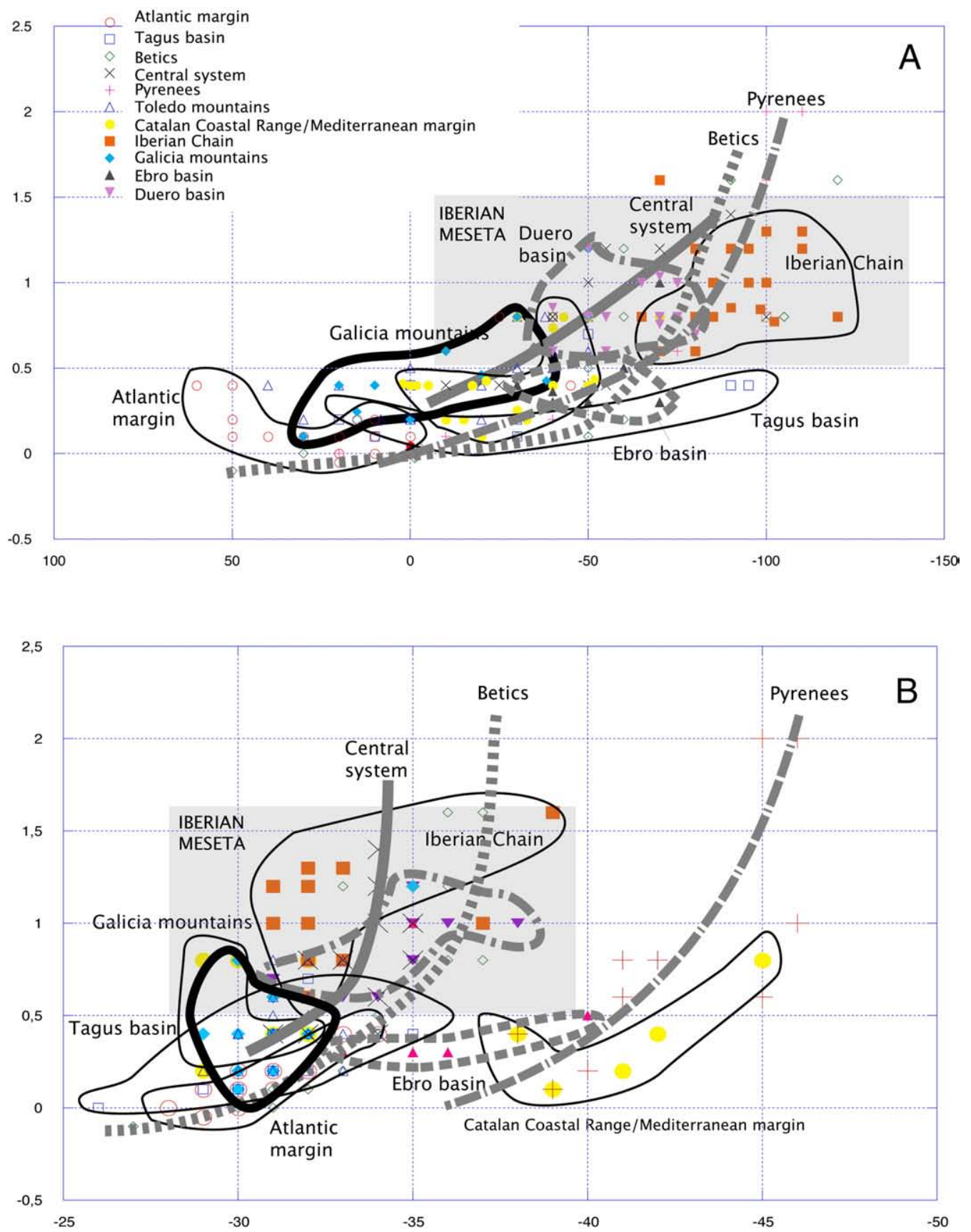

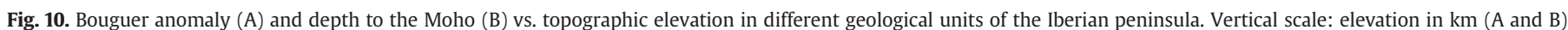
Horizontal scale: $\mathrm{mGal}(\mathrm{A})$ and $\mathrm{km}(\mathrm{B})$.

correlation between elevation and crustal thickness, which supports a compressional/isostatic origin for most part of the uplift of the Iberian Meseta.

\subsection{The evolution from endorheism to exorheism: geomorphological constraints}

Low-level topography areas within the Iberian plate are linked to (1) coastal plains delimited by Oligocene-Miocene normal faults (Mediterranean coast), in continuity with the offshore plains of the Valencia Trough or the Algerian basin, or related to the Atlantic margin (Atlantic coast), (2) externally drained basins formed during compressional deformation of the plate (namely the foreland Gua- dalquivir Basin, limiting the southern part of the Iberian Meseta), (3) Tertiary, internally-drained basins captured by the fluvial network during the Miocene or the Plio-Quaternary (García-Castellanos et al., 2003). Sedimentation during the Neogene throughout the Iberian microcontinent (Fig. 9) was of alluvial/lacustrine type, with alluvial fans sourced in the residual relief areas of the eroded mountain chains surrounding the basins (Cantabrian mountains, Pyrenees, Iberian Chain, Central System, see e.g. Casas et al., 2000b). The occurrence of endorheic basins within the plate during this period (Fig. 11) is a particular feature of Iberia. This conditioned landscape development in the Iberian plate during all the Tertiary and the Quaternary (e.g. Coney et al., 1996) evolving under the following constraints: 


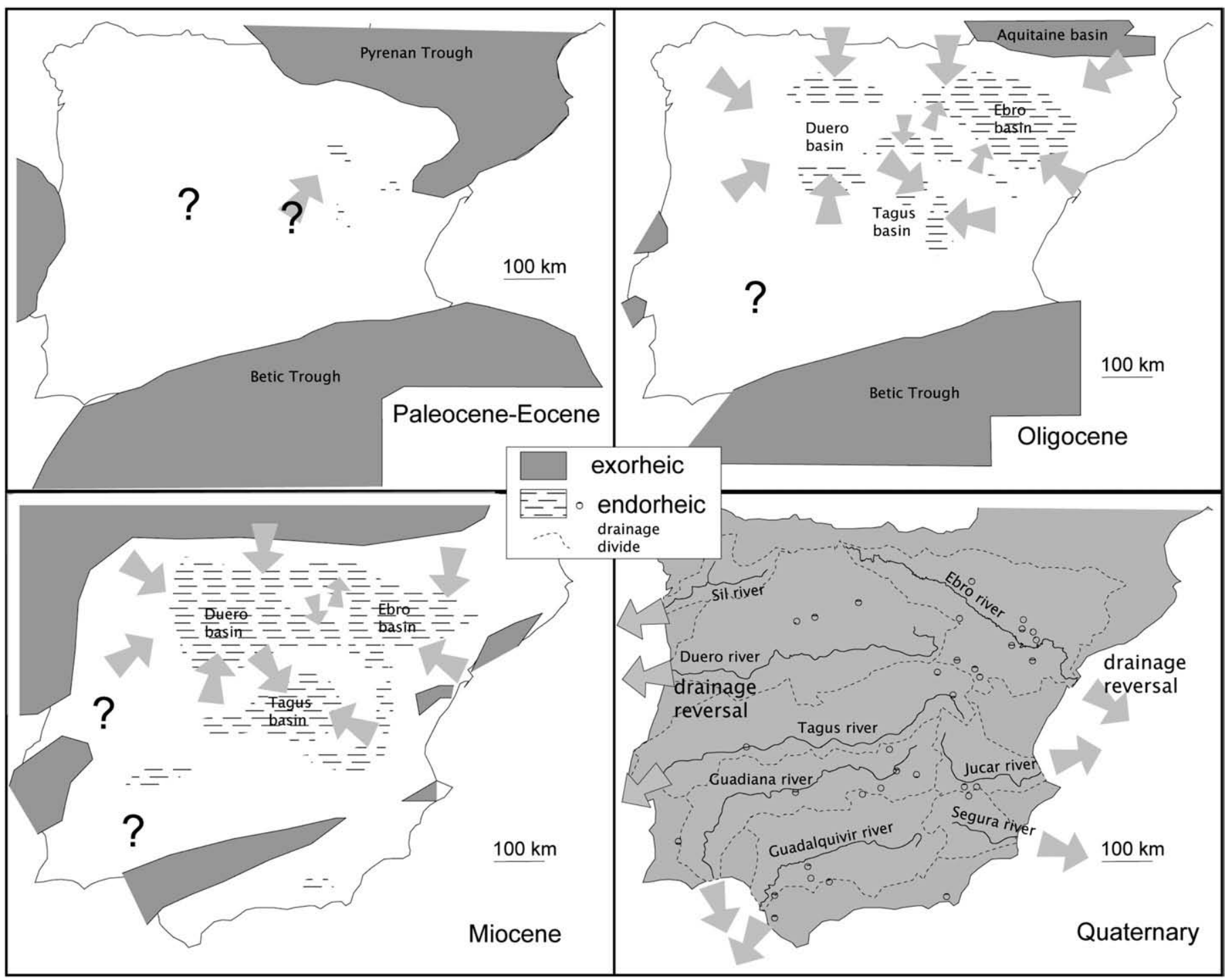

Fig. 11. Evolution from endorheism to exhorheism in the Iberian peninsula through the Tertiary. Endorheic areas progressively reducing in surface with time.

- Because of the high base levels (continuously rising during the filling of the basins), endorheic deposition preserved the massifs of Palaeozoic and Mesozoic rocks from deep erosion. However, the absolute height of base levels during the stage of formation of planation surface is not known and information on this aspect can only be obtained from geological markers (i.e., geometry of the Upper Cretaceous marine limestones) and morphological features along the western and eastern coasts.

- Deposition in endorheic basins contributed to relatively high deposition rates, accommodation space resulting not only from tectonic subsidence but also from topographic differences between source areas (mountains) and basins (endorheic plains). This makes a difference with exorheic areas, and allowed for a thorough sedimentary record of the Neogene to be deposited at the three main endorheic basins (Ebro, Duero and Tagus).

- Deposition in basins bounded by mountain chains created a particular environment of isostatic conditions at the basin scale, because of the sedimentary filling of previous air-filled troughs, with differences in density higher than $2000 \mathrm{~kg} \mathrm{~m}^{-3}$ (see discussion on this topic in Casas et al., 2000b).

Since the Late Miocene-Pliocene, endorheic basins were captured by the present-day fluvial network. This process was linked to: (i) regressive erosion in the Ebro Basin (García-Castellanos et al., 2003; Babault et al., 2006). Although the capture of the endorheic Ebro Basin was not directly related to tectonics, extensional movements by normal faulting (negative inversion) with downthrown blocks toward the Mediterranean coast and the offshore (Roca and Guimerà, 1992; Roca, 1994) were responsible for narrowing the mountain threshold separating the endorheic Ebro basin from the sea and thus for facilitating the capture of the basin. (ii) in the Duero and Tagus basin, flowing into the Atlantic at the passive margin, the endorheic-exorheic transition was probably also driven by regressive erosion. It was easier and more advanced in the case of the Tagus basin (Martín-Serrano, 1991). According to other authors (De Brum Ferreira, 1991), vertical movements in the onshore of the Atlantic coast could also be responsible for both lowering the coastal plains and hampering the Duero Basin from erosion during the Quaternary.

River profiles reflect the main landscape features of the Iberian plate and the endorheic/exorheic transition: The Duero fluvial basin, draining the weakly-eroded Tertiary Duero basin, shows a strong inflection where passing from the Tertiary basin to the coastal plain across the Vilariça Fault System (see Figs.1, 3 and 7). Similar features can be observed in the Sil river, that drains the northernmost part of the Duero basin and is strongly incised in recent times (Fig. 5), and 
in the Alagon river, a tributary of the Tagus that is also cutting into the Duero Basin. The Central System, that separates the Duero and Tagus basins, also shows an unusual drainage pattern, with the water divide closer to the Duero Basin, thus inducing a south-directed drainage (towards the Tagus) for almost all of the internal range rivers. Along its longitudinal profile, the Tagus river shows a profile with a headward step farther east with respect to the Duero river, probably reflecting the boundary of the Neogene endorheic zone (Fig. 7). The Ebro river, because of the pronounced erosion of its basin during the Pliocene/Quaternary shows a rather even profile and represents a more advanced stage of basin erosion (less than 400 m mean elevation) than the Duero basin (close to 900 m mean elevation in ints eastern part), with high levels of probable Pliocene age preserved only in the westernmost part of the basin (Gonzalo Moreno, 1979; Villena et al., 1996). As a summary, the Duero fluvial basin is being captured by all adjacent fluvial basins: The Ebro river to the E, the Sil river to the $\mathrm{N}$ (Fig. 5A) and the Tagus river to the S. Different hardness of rocks being incised can be used as a reason to explain this situation with respect to the Tagus, but not for the Sil river.

The other rivers on the Mediterranean side (Turia and Jucar) show more uneven profiles (Fig. 7), with sudden changes at about $600 \mathrm{~m}$ a.s.l. to join the low-relief surfaces corresponding to the eastern part of the Iberian Meseta. These non-regular profiles can be interpreted as early stages of the evolution towards regular profiles resulting from young extensional tectonics near the Mediterranean coast lowering the local base level. The Segura river occupied the lowlands created by extensional tectonics in the Alboran domain and the Algerian basin, its source area is located in the External Betics and its longitudinal profile indicates that the Segura River is not related with the Iberian Meseta.

As reflected by the westward pinchout of Upper Cretaceous sediments, which are widespread in the eastern part of the Iberian Peninsula, the paleo-topography (at the Iberian massif, western part of Iberia) during the Late Cretaceous was high enough to allow for Palaeozoic rocks to emerge above sea level during the Cretaceous sealevel rise. From geological data Palaeozoic paleo-reliefs can be estimated to be at least $100 \mathrm{~m}$ higher than the surrounding flat surface, because this is the elevation difference between Palaeozoic residual reliefs and the lowermost depositional Tertiary level. This paleotopography is consistent with estimates established assuming local isostasy (c.f. Gaspar-Escribano et al., 2004; De Vicente et al., 2007). The residual topography is calculated from observed Tertiary sediment thickness and observed topography in the Tagus and Duero basins. From the assumption that positive values of residual topography reflect Mesozoic paleo-topography, a paleo-topography of ca 200-300 m can be interpreted in the western part of the Tagus basin, and a higher paleo-topography, up to $800 \mathrm{~m}$, in the western part of the Duero Basin. The interpreted paleo-topography is consistent with increased regional crustal thickness (excluding sediments) interpreted in the gravity profiles of the Central System (De Vicente et al., 2007). During the Oligocene-Middle Miocene, sediments were transported from the topographic highs in the West to the lows in the East. The Tagus and Duero basins became starved, and their eastern parts gradually overfilled causing a levelling of the topography in the western and eastern basins. At a later stage, a drainage reversal gave way to the Atlantic polarity of the Tagus and Duero Basins, favoured by a gentle tilting towards the SW. In the Tagus basin this can be deduced from the dipping of the Upper Miocene lacustrine limestones, initially related to the uplift of the Central System with alluvial fan systems prograding toward the SE. This could also suggest some kind of general uplift of the Iberian Chain.

The other two main rivers on the Atlantic side of the Iberian peninsula, the Guadiana and the Guadalquivir (Fig. 6) show even and low profiles, determined by their evolution within exorheic basins located between uplifted areas by recent lithospheric folding (De Vicente et al., 2007), therefore defining a strong difference between the northern (Iberian Meseta) and the southern halves of the Iberian peninsula. The only exception is the upper Guadiana basin, with Tertiary endorheic evolution and recently captured by both the Guadiana and the Jucar rivers. The lower part of the Guadiana basin could also be conditioned by horts and graben parallel to the N-S coastline as interpreted by De Brum Ferreira (1991). In any case, the marked regularity of the fluvial network pattern of the centralwestern part of Iberia (Sil, Duero, Tagus, Guadiana and Guadalquivir) is an argument favouring global lithospheric folding (Cloetingh et al., 2002).

\subsection{Lineament-controlled drainage pattern in the endorheic basins}

The present-day morphology of the main Tertiary (endorheic) basins (Ebro, Duero and Tagus) is strongly conditioned by fractures (detected from lineament mapping of satellite images, digital elevation models and aerial photographs, Fig. 12). In this paper we consider that lineaments are straight linear features, presumably expressing a subsurface phenomenon, that differ distinctly from the patterns of adjacent features (Sabins, 1987). These lineaments show a NE-SW dominant trend in the Duero and Tagus basins (Giner, 1996; Cortés et al., 1998; Casas et al., 2000a; Cortés et al., 2003) and WNW-ESE in the Ebro basin (Arlegui and Simón, 2001; Arlegui and Soriano, 2003), coinciding with the trend of the main rivers or their main tributaries (Fig. 12).

Lineaments are the result of fracturing, or at least there is a coincidence between orientation of lineaments and faulting (Cortés et al., 1998), with fractures showing, in general at outcrop scale, small or null displacements (small-scale faults and joints), affecting horizontal or sub-horizontal beds of different kinds of Neogene rocks (sandstones, limestones and evaporites, Arlegui and Simón, 2001; Arlegui and Soriano, 2003). The different development of morphological lineaments, in different areas of the same basin, and between the different basins can be related to the exhumation/erosion velocity during the Pliocene/ Quaternary and to the orientation of fractures compared to the fluvial network. In general, lineaments are much better developed in the Duero basin compared to the Ebro basin, and, within the Ebro basin, its central part shows better defined lineaments than its eastern part. This can be explained by a worse development of morphological lineaments (i) where exhumation and erosion was stronger (Ebro basin vs. Duero basin), and (ii) where the main rivers or tributaries are oblique or almost perpendicular to the main fracture trends ( $\mathrm{N}-\mathrm{S}$ tributaries in the eastern part of the Ebro basin). A different lineament distribution is found at the Tagus basin, where lineaments are much more evident when approaching the Iberian Chain (eastern part).

In the Duero basin most lineaments can be interpreted as the reactivation of faults in the Variscan basement, since their main trends coincide with previous crustal heterogeneities (e.g. The Messejana Fault, see location in Fig. 1 is nucleated on a large Jurassic basic dike) and different geological units located at its borders (Cortés et al., 2003). Some gentle tilting to the $\mathrm{E}$ can be observed in the terrace architecture of southdirected streams in the NW corner of the basin. The maximum age for the fracturing stage can also be constrained from the age of the highest affected unit, which is Late Miocene to Pliocene (Mediavilla et al., 1996; Santisteban et al., 1996). However, little is known about the origin of the tectonic regime causative for fracture movement, since opening of joints may occur under either wrench, extensional or isostatically-driven regimes (Hancock, 1985; Simón et al., 1999; Arlegui and Simón, 2001).

In the Ebro basin, most faults on Neogene materials are interpreted to be of extensional origin (Simón et al., 1999; Arlegui and Simón, 2001) and could also correlate with ancient fracture trends. These trends are NE-SW in the Catalonian coastal range, located in the eastern boundary of the Ebro basin, and NW-SE in the Iberian Chain (that forms the southern boundary of the Ebro basin) where very similar lineaments are found. (Fig. 12). The dominant WNW-ESE 

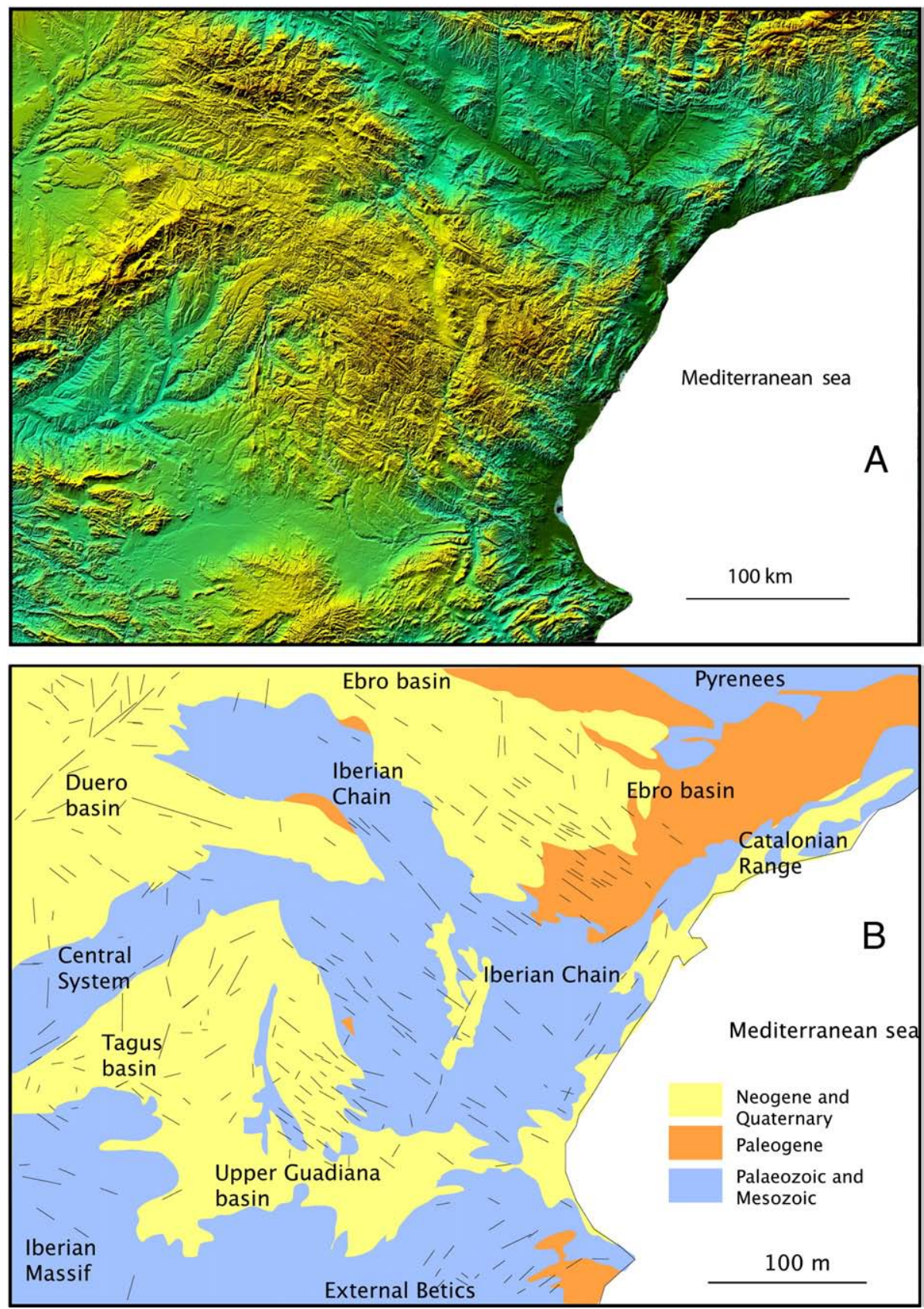

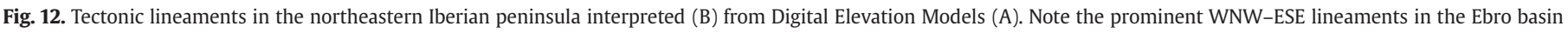

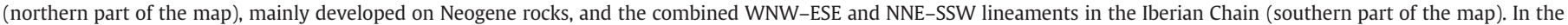
northwestern corner of the figure the NE-SW lineaments dominant in the Duero Basin can be interpreted.

fracture set in the Ebro basin has been related to extensional movements (multidirectional extensional regime) linked to the opening of the Valencia Trough in the East (Simón Gómez, 1989; Capote et al., 2002). The age of fracturing in the Ebro basin is not so well constrained as in the Duero basin, because most fractures are preserved on rocks of Middle Miocene age, and outcrops of rocks of Late Miocene age do not allow for lineament analysis, therefore only a very vague lower limit can be given for this late fracturing stage.

In the Tagus basin, fracturing on Upper Miocene sediments do not allow to establish a general stress regime (Giner, 1996), but a clear difference is observed with respect to the other basins: intense Quaternary faulting activity caused a straight NE-SW graben in the lowermost part of the Jarama stream, with continuous sedimentation and subsidence of more than $100 \mathrm{~m}$ thickness of fluvial sediments.
It is highly probable that older rocks throughout the Iberian plate also underwent this fracturing stage, although it is very difficult to recognise because of the superposition over older deformation periods (Late-Variscan faulting, Mesozoic extension, Tertiary compression, etc.). In an overall view, lineament maps indicate the prevalence of the dominant NE-SW and NW-SE trends all over the Iberian Variscan Masif (see e.g. Arthaud and Matte, 1975).

\subsection{Uplift indicators}

No systematic work has been done up to date to summarise geomorphological and thermochronological evidences of uplift during the Quaternary, and to correlate the different sectors of the Iberian Meseta. Therefore, their quality and reliability cannot be 
completely assessed at present. However, in our opinion several indicators of uplift can be used as a record for recent movements in different parts of the plate:

- Stepped terrace levels of Quaternary alluvial deposits along the main Pyrenean rivers (Lewis et al., 2000; Sancho et al., 2004), indicating recent differential uplift of the mountain range with respect to the Ebro Basin, although other fluvial terrace systems in Iberia seem to be more influenced by climatic and eustatic controls (Santisteban and Schulte, 2007).

- Pliocene elevated marine terraces of the N Cantabrian Mountains (rasa paleosurfaces), with apparently reversed movements (sinking) in the Galicia margin (De Brum Ferreira, 1991).

- Stepped erosion surfaces in the Atlantic coast (De Brum Ferreira, 1991), indicating a differential uplift of about $900 \mathrm{~m}$ according to this author.

- Fission tracks analyses indicate an accelerated Pliocene uplift of the Central System (De Bruijne and Andriessen, 2002) and the Catalonian Range (Juez-Larré and Andriessen, 2002), that can be related to morphological features (Tejero et al., 2006).

\subsection{Recent stress field and seismicity}

Onshore large-scale structures of Neogene and Quaternary age are concentrated in the southern plate margin (Betic Chain and its foreland), the northeastern sector (Catalonian Coastal Range), the Eastern part of the Iberian Chain and the Atlantic margin. Within the Iberian Meseta large-scale Neogene and Quaternary structures are rare. However, several domains can be distinguished (mainly from analysis of small-scale structures and earthquake focal mechanisms) according to the main faulting mechanisms during the Neogene and the Quaternary:

- In the Ebro basin and the Iberian Chain recent extensional paleostresses (triaxial extension) and focal mechanisms are dominant (Muñoz-Martín et al., 1998; Herraiz et al., 2000; De Vicente et al., 2008). A similar pattern (Souriau and Pauchet, 1998) is found in the Pyrenees and the Catalonian Coastal Range, where the main kilometric-scale recent faults (in general with a NE-SW trend) can be found (Masana, 1994). At the Pyrenees, recent stress inversions from moment tensor focal mechanisms (De Vicente et al., 2008) indicate the prevailing of normal faulting parallel to the main topographic highs. It could indicate some ongoing isostatic compensation of the mountain range and the clear cessation of active thrusting.

- In southern Spain, seismicity and recent faulting are linked to the Africa-Iberia convergence in a NW-SE direction postdating the An5 (Late Miocene) anomaly (Rosenbaum et al., 2002), with normal (centre), reverse (West) and strike-slip (East) faulting (Andeweg et al., 1999; De Vicente et al., 2008), the latter dominantly dextral along the ENE-WSW lines parallel to the northern boundary of the Guadalquivir basin.

- In onshore areas linked to the western Iberian margin (N Spain and Portugal) focal mechanisms and recent faulting are extensional, compressional and strike-slip (Cabral, 1989; Ribeiro et al., 1996; Borges et al., 2001), although a relative dominance of strike-slip faulting compatible with NW-SE compression seems to exist, with thrusting mechanisms increasing towards the S (Stich et al., 2006; De Vicente et al., 2008).

Spatial distribution of seismicity in the Iberian plate defines the marginal areas of the Iberian Meseta, whereas seismicity within the Meseta is scarce and limited to areas with important Tertiary thrusts (Cameros massif, Central System) or with strike-slip and extensional faults formed during the Mesozoic and the Tertiary (Iberian Chain-Vilariça F.S.), where probably the continental crust is much weaker (Van Wees and Stephenson, 1995). The instrumental seismicity is more important in the Tagus Basin than in the Ebro and Duero basins, in agreement with its more relevant Quaternary faulting.

\section{Discussion}

What is the origin for the high elevation of the Iberian Meseta? From the set of data here presented, two, not incompatible origins, can be proposed, since probably both of them contributed to the development of the present-day landscape. The contribution of each of these two factors is still a matter of controversy, and new data are necessary to established a well-defined model for the recent landscape evolution of the Iberian peninsula (Fig. 13):

- Alpine (mainly Cantabrian-Pyrenean related) compressional tectonics was the principal responsible for closing internally-drained sedimentary basins (Ebro, Duero, and partially, Tagus). The baselevels for these internally-drained areas were progressively higher because of their filling with sediments sourced in the bounding mountain chains. Lithospheric folding contributed to the isolation of terrestrial sedimentary basins within the plate.

- A recent stage of uplift, along with fracture re-activation, probably related to the present-day seismicity and plate kinematics resulted in rising the Iberian low-level topography, as interpreted from geomorphological evidences. Because of the predominant normal faulting focal mechanisms in the Pyrenees and the Iberian Chain, isostatic rebound subsequent to crustal thickening could be interpreted as the source for this late uplift.

Are both causes compatible with the convergent regime (AfricaIberia-Europe) prevailing in the Iberian plate since Late Cretaceous times? The Pyrenean compression was the responsible for the thickening of the Iberian crust, specially along mountain chains, and gave rise to lithospheric folding as far as the Anti-Atlas. The movement of the Alboran domain in a westward direction brought about the subsequent decoupling of the lithosphere. Decoupling was diachronous, since it began in the eastern part of Iberia and progressively moved towards the West. Accordingly, the coupled crust-mantle system with prevalence of $\mathrm{N}-\mathrm{S}$ convergence is still active in the westernmost part of Iberia (Gulf of Cadiz and the Lusitanian basin), where the effect of decoupling due to the emplacement of the Alboran domain is not recorded at present. The isostatic rebound subsequently followed decoupling, especially in eastern Iberia, the Pyrenees and the Iberian Chain, with little influence of the Betic compressional system. According to this hypothesis, the endorheic-exorheic transition in the Duero basin could be a delayed, far-field effect of the mechanical decoupling between Iberia and Africa.

Why are high areas at similar heights, and what has then hampered erosion of the Duero basin and the upper part of the Guadiana basin? According to De Brum Ferreira (1991) during the Neogene uplift basins and horsts formed at the Atlantic margin partly hampered the erosion of the Duero basin. However, this hypothesis avoids considering the very origin of the Duero endorheic Paleogene basin, that should be closed to the ocean in its western part during most part of the Tertiary, because of the transpressional activity of left-lateral NNE-SSW faults. Structures resulting from this activity were probably the responsible for closing the western basin boundary but their re-activation during the Neogene and Quaternary is difficult to estimate from present-day available data, since, as demonstrated by Babault et al. (2007) planation surfaces can form at different heights in mountain ranges.

The different filling and evolutionary pattern between the eastern and western Tagus Basin can be explained as related to the mechanical decoupling between Iberia and Africa during the emplacement of the Alboran domain (Miocene) in the southern part of the plate, allowing 
1) OLIGOCENE. COMPRESSIONAL DEFORMATION. BEGINNING OF FORMATION OF ENDORHEIC BASINS.

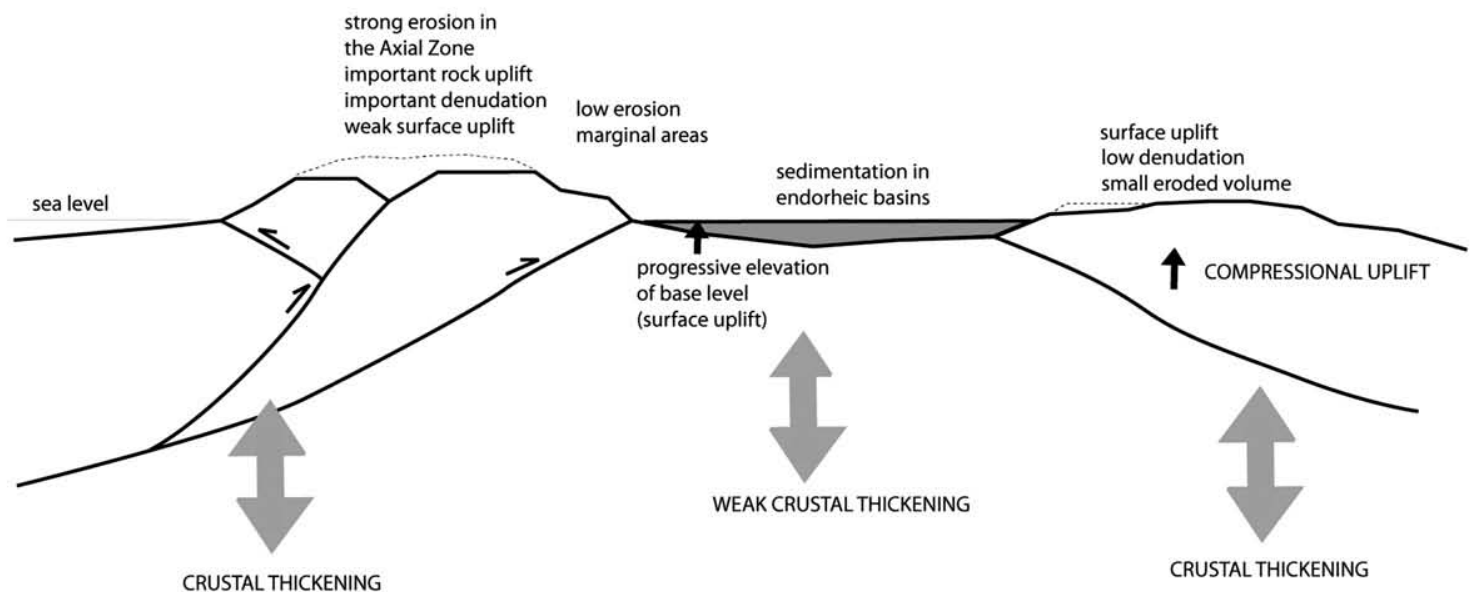

2) MIOCENE. PLANATION SURFACES. END OF SEDIMENTATION IN ENDORHEIC BASINS. COMPRESSIONAL UPLIFT.

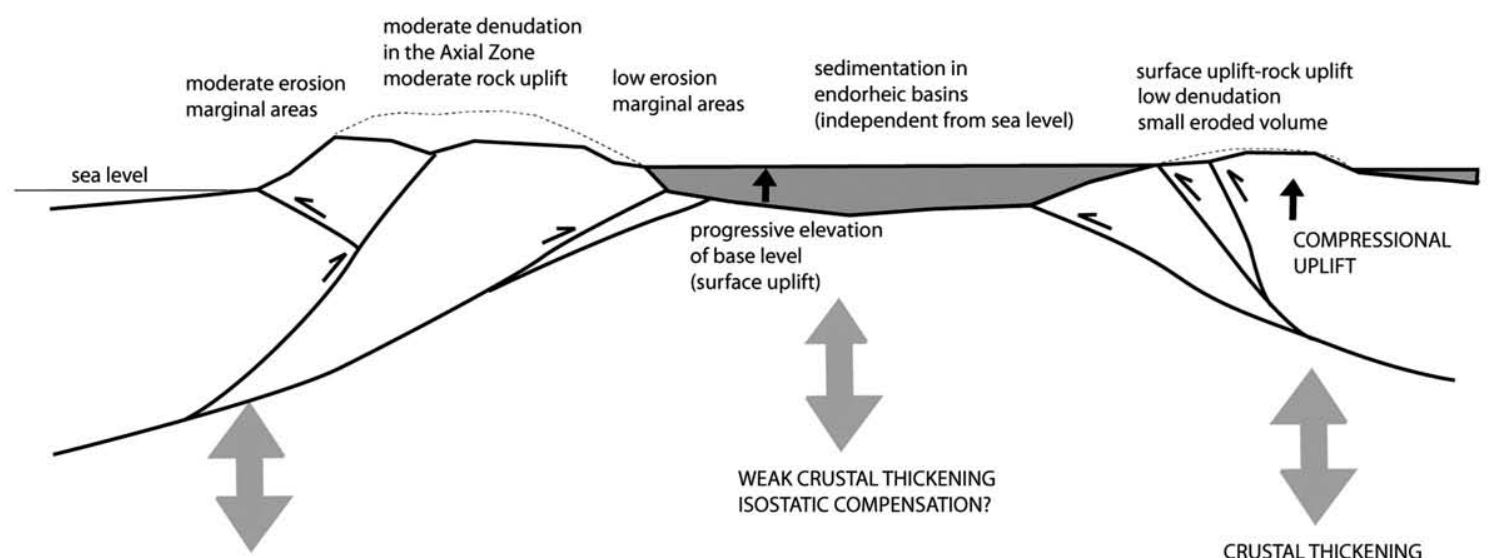

CRUSTAL THICKENING

CRUSTAL THICKENING

\section{3) PLIO-QUATERNARY. EXORHEISM. ISOSTATIC UPLIFT}

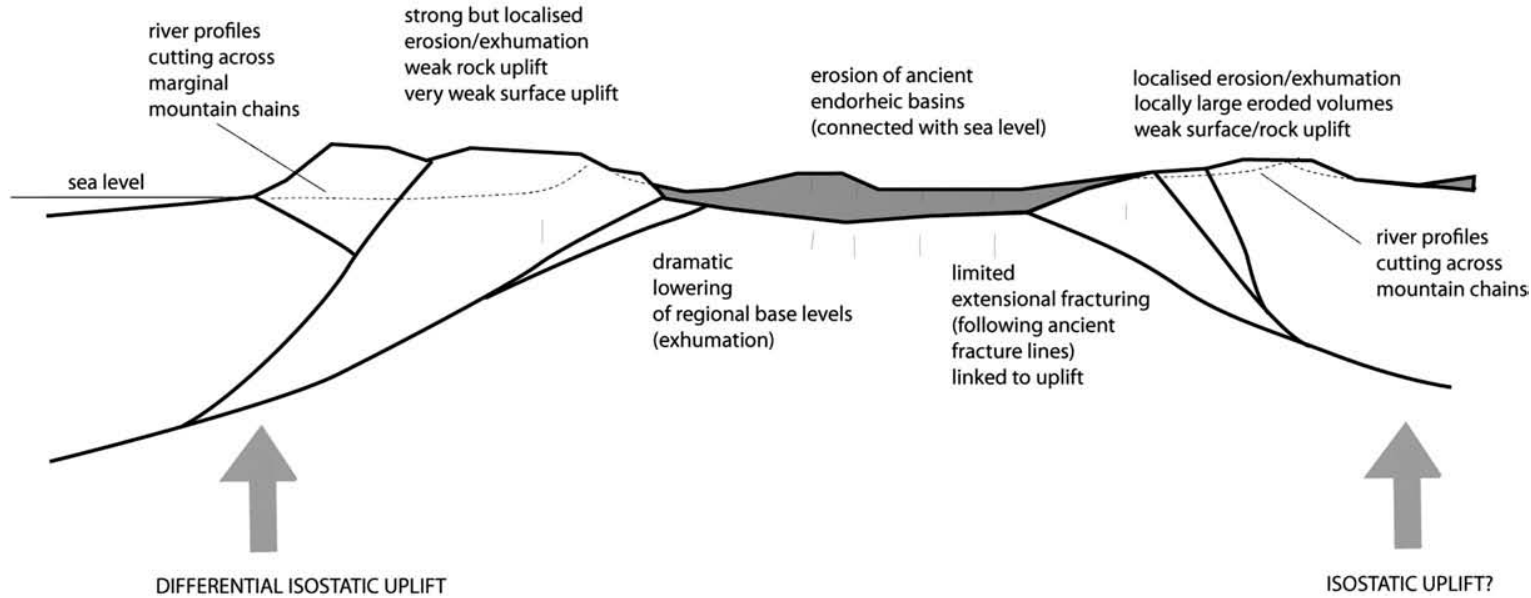

Fig. 13. Conceptual sketch showing the evolution of the Iberian Meseta during the Tertiary and the Quaternary. See text for explanation. 
for extensional stresses in the Eastern Iberian plate to be generated (Fig. 2). At this time, extension in the eastern part of the Iberian plate co-existed with compression and lithospheric folding in the western part of the plate (De Vicente et al., 2008; De Vicente and Vegas, 2009this issue).

South of the Tagus basin, the present day fluvial network cannot be interpreted as the result of endorheic/exorheic transition because of the continued thrusting activity during the Neogene (and until present) of the Portuguese Central System (Ferreira-Soares et al., 2005; Stich et al., 2005). The Guadalquivir basin has been also interpreted in terms of foreland basin evolution (see e.g. Sanz de Galdeano, 1996).

Climatic constraints should also be considered as a possible contribution for some of the changes occurring between the Tertiary and the Quaternary, like the reversal in drainage in the marginal areas of the endorheic sedimentary basins. The formation of planation surfaces on Palaeozoic and Mesozoic rocks during most part of the Tertiary is interpreted to be the result of pediplanation processes (Gutiérrez Elorza and Gracia, 1997; Casas and CortésGracia, 2002, and references therein, see Fig. 5B,D). Global sedimentation rates increased during the Pliocene and the Quaternary (Peizhen et al., 2001) and therefore can account for an influence in drainage change and coarse deposits overlying many of the remnants of previously formed planation surfaces.

When comparing the highly elevated Iberian peneplains with other elevated areas in the Eurasian alpine fold belt (Fig. 14) differences arise especially when considering the area involved and the amount of uplift or elevation in each case. Since most of them were developed under a well-established tectonic regime, some hints can be obtained for the evolution of the Iberian Meseta (Fig. 14). In general, dimensions of peneplains linked to extensional histories and passive margins (oldlands on the Laurasia and Gondwana continents, e.g. Kooi and Beaumont, 1994; Peulvast and Sales, 2004; Jaspeen et al., 2006; Tinker et al., 2008) are larger and their evolution includes time spans longer than the uplift evolution of the Iberian Meseta. In addition, the uplift and evolution of some of these areas is closely linked to glaciation-deglaciation processes. Peneplains linked to compressional tectonic histories or convergent regimes in Anatolia and central areas of Iran, Morocco and Afghanistan (Fig. 14) are comparable in size to the Iberian plate. Furthermore, their tectonic setting is also similar, since they are located in the overriding, continental plate of the African-Eurasia subductioncollision system. Two of them (Iran and Anatolia) also show a complex system of high plains including both areas of erosion (planation surfaces) and sedimentation (basin filling surfaces). In the case of Iran, the development of planation surfaces is relatively scarce with respect to the Iberian plate (i.e. high plains of Firuz Kun and Sanbardan within the Alborz mountains), and they are strongly dissected by the fluvial network, but their structural position and morphological features are comparable with Iberian surfaces. The different extension of this kind of surfaces with respect to the Iberian peninsula can be related to the stronger tectonic activity and higher topography in Iran. Since planation surfaces are formed by pediplanation processes, long periods of slow deformation rates favour the wider development of this kind of surfaces (see e.g. Casas and Cortés-Gracia, 2002). A similar context can be found in Anatolia (i.e. around the Tuz Gölü endorheic basin), where the development and dissection of different levels of planation surfaces are strongly influenced by Tertiary and post-Tertiary tectonics (see e.g. Dhont et al., 1998; Tokay and Altunel, 2005). Taking into account the age of the compressional deformation, the Iberian Meseta can be considered an ancient analogue at slower convergence rate for the present-day endorheic, intramountain basins of Middle-East Asia. In northern Africa (Atlas mountains) faulting of planation surfaces by reverse faults and thrusts and overall uplift is associated to the areas of active deformation (i.e. Morel et al., 2000; Sébrier et al., 2006), whose moderate activity during the Pliocene and the Quaternary can be compared to the Iberian Chain and Central System during the Paleocene and early stages of the Neogene and also provide a modern analogue for the evolution of the Iberian peninsula, combining basement thrusting, basin inversion (Arboleya et al., 2004), pediplanation and faulting of planation surfaces.

From the crustal thickness-elevation relationships a hypothesis of isostatic uplift (probably erosion-triggered during post-Neogene times) can be proposed for much of the recent uprising of the Iberian Meseta, and contributions from uplift of rift shoulders in an extensional setting (i.e. opening of the Valencia Trough) is probably a minimum percentage of the total recent uplift. This is consistent with the extensional re-activation of ancient fracture lines, even though a convergent regime between Africa and Iberia still exists, that probably was not able to transfer compressional stresses to the inner part of the plate (De Vicente and Vegas, this volume). Pervasive recent (post-Neogene) fracturing, as determined from lineament analysis throughout the Iberian peninsula is the result of re-activation of Late-Variscan fractures with different orientations, with dominant directions changing in different areas of the Iberian peninsula (NE-SW to NNE-SSW in the Duero basin and the Portuguese basement changing to WNW-ESE to NW-SE in the Iberian Chain and Ebro Basin). Post-Neogene fracturing can be interpreted as the result of recent and present-day extensional movements near the topographic surface (see e.g. Antolín et al., 2008), consistent with the stress field in the upper crust determined from focal mechanisms and compatible with the erosiontriggered isostatic uplift of the Iberian microcontinent. Although some of the geodynamic models proposed emphasise the role of extensional tectonics recorded in the Mediterranean margin in the uplift of the Iberian Meseta (cf. Introduction section), in our opinion extension did not increase the mean elevation of the Iberian Chain and the Catalan Ranges, but induced the downwards movement of the eastern blocks of faults toward the Mediterranean side, consistent with crustal thinning as evidenced from gravimetric data.

Recent volcanism in the inner part of the Iberian plate may suggest a contribution from thermal activity to the uplift of the Iberian Meseta. However, Neogene and Quaternary volcanic activity is strongly localised and, in our opinion the crustal thickness pattern and thermal flow distribution (Fernàndez et al., 1998) prevents interpreting an important contribution from thermal uplift, as it occurs in other areas of the Mediterranean belt (see e.g. Arboleya et al., 2004; El Harfi et al., 2006), although new data from the Iberian mantle are needed to discard this hypothesis.

From the data and discussions here presented it is evident that, in spite of the amount of data existing up to date, there is still much work to be done to unravel the origin of the Iberian Meseta, and especially the contributions of Tertiary and Quaternary uplifts and the causes for vertical movements. In our opinion, future works to be done should include the following aspects:

- precise dating of deformation along recent faults, that will allow for a chronological reference frame of different movements in the different parts of the plate to be established. Furthermore, the determination of movement rates along faults can help to constrain rates of uplift for the different domains.

- dating of deposits linked to recent events, especially those linking the endorheic and exorheic stages in the different basins.

- establishing the relationships between recent faults and seismicity in the margins and inner part of the plate.

- dating the exhumation of the mountain chains and their relationships with the filling of the foreland basins.

- determining the palaeoclimatic evolution linked to changes in elevation of endorheic sedimentary basins would help the reconstruction of paleoelevations in different basins in an independent way and compare the results with exhumation obtained from fission track data. 

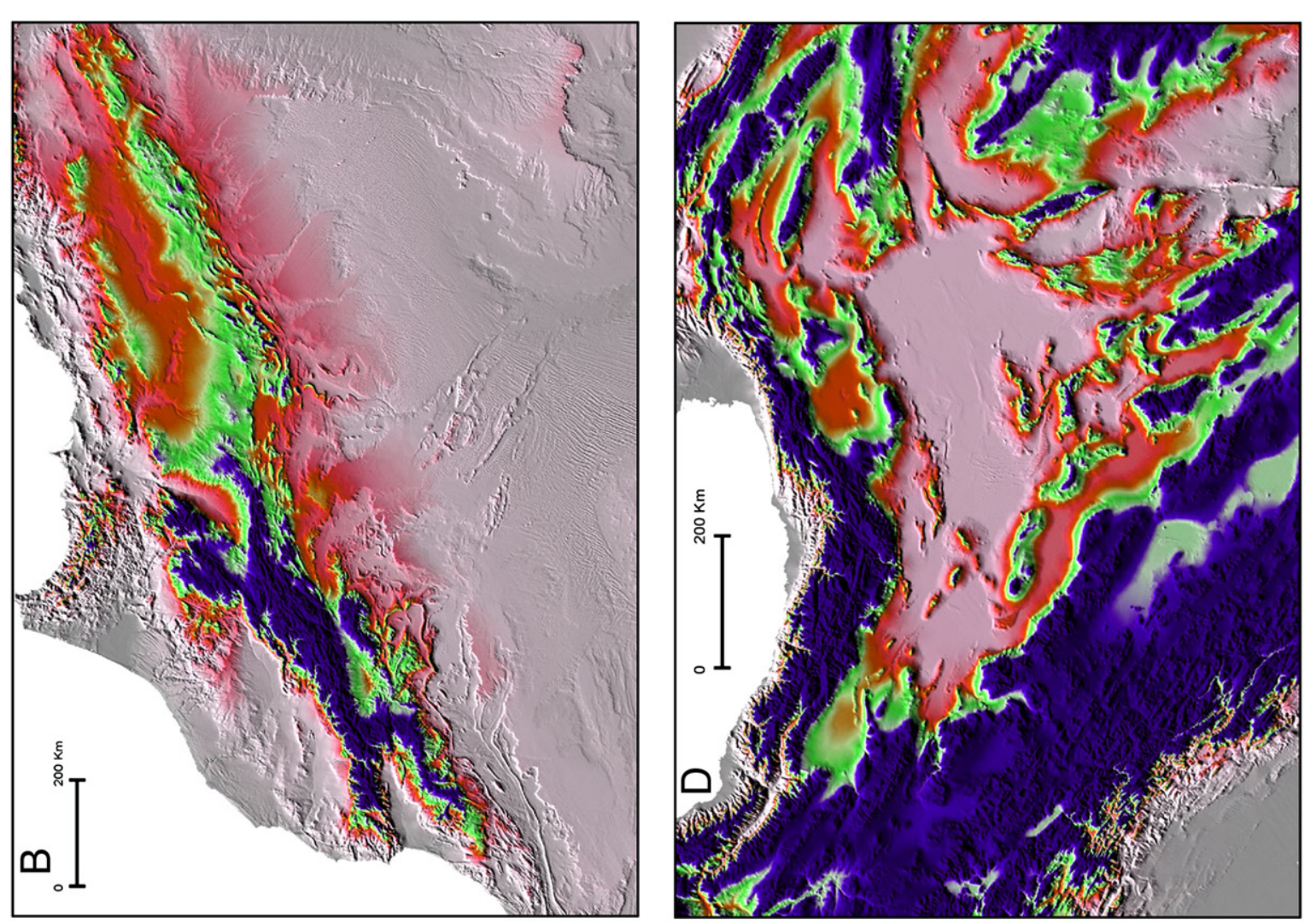

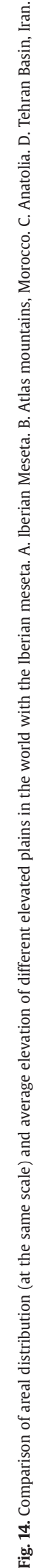

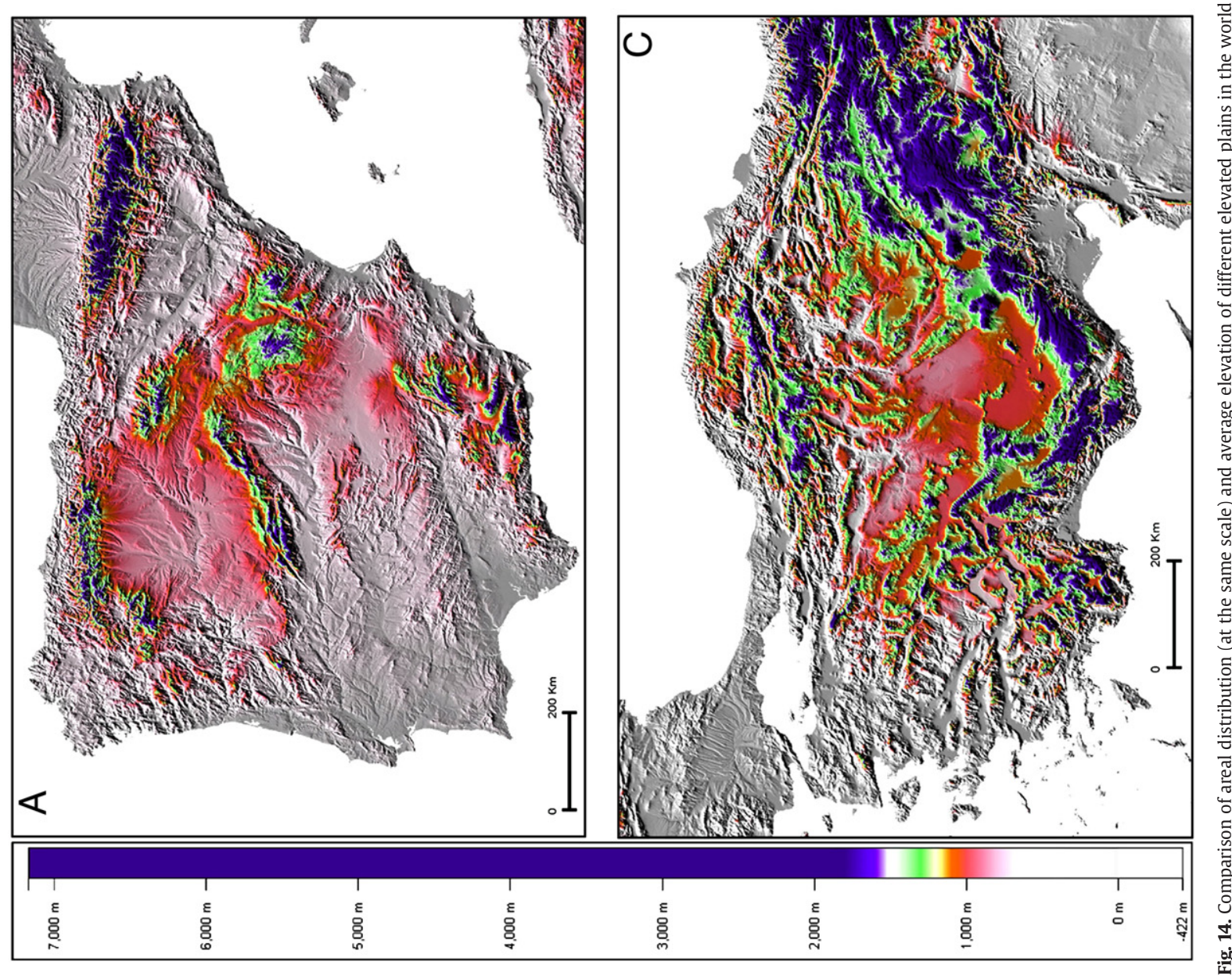




\section{Conclusions}

The Iberian Meseta stands as one of the main features of the Iberia microcontinent, and can be considered as consisting of a complex system of surfaces that form a low relief landscape. From the geological point of view these surfaces resulted either from erosion or sedimentation along the Cenozoic history (Paleogene to present) of the Iberian microplate.

In our opinion, the morphological, geophysical and structural features of the Iberian Meseta, (including its topography, fracturing, seismicity, etc.), can be explained after an important contribution (Fig. 13) from Alpine compressional or transpressional deformation (uplift of the Pyrenees, Iberian Chain-Catalonian Coastal Range, Central System, western margin of the Duero basin and Betic Chain) that delimited the main uplifted areas and the endorheic basins during most part of the Tertiary.

The other main contribution to the formation of the Iberian Meseta was the recent uplift (Fig. 13) of the northern part of the Iberian plate (the Iberian Meseta) as a result of plate-tectonics configuration, derived from the important role played by the decoupling induced by the emplacement of the Alboran domain in southern Iberia during the Europe-Iberia-Africa convergence. Isostatic adjustment resulting from crustal thickening, erosion during the endorheic-exorheic drainage transition and the lithospheric folding process in southern Iberia (also resulting in elevation of intra-basinal areas) were different results of this process. Disgracefully, at the present state of knowledge about the evolution of the Iberian plate, it is not possible to quantify either the contribution of both processes or the absolute age of uplift during its Cenozoic history. Future works considering tectonic and climatic inputs will be necessary to unravel the Cenozoic history of the Iberian Meseta.

\section{Acknowledgements}

The authors are very grateful to the Guest editor (Sierd Cloething) and three anonymous referees for their careful revision of the manuscript that helped to improve very much the original text. Tania Mochales helped with some of the photographs. This work was supported by projects CGL2006-05817/BTE, and CGL2006-02514 of the Dirección General de Enseñanza Superior (Spanish Ministry of Education), by the Consolider Ingenio 2006 "Topo Iberia” CSD200600041 and the Spanish National Research Program CGL2006-13926C02-01-02 "Topo Iberia Foreland". These projects are a part of the Spanish contribution to TOPO-EUROPE.

\section{References}

Alcalá, L., Alonso Zarza, A.M., Calvo, J.P., Morales, J., Sanz, M.E., 1994. Litoestratigrafía y Paleontología del área tipo del Turoliense (Mioceno superior continental). II Congreso del G.E.T., Comunicaciones, Jaca, Spain, pp. 11-14.

Alcalá, L., Alonso Zarza, A.M., Anadón, P., Calvo, J.P., Ortí, F., Rosell, L., van Dam, J., 1997. Neógeno de la fosa de Teruel. In: Alcalá, L., Alonso Zarza, A.M. (Eds.), Itinerarios geológicos en el Terciario del centro y este de la Península Ibérica. Guía de Excursiones del III Congreso del G.E.T., UCM-CSIC, Cuenca, Spain, pp. 7-38.

Alcalá, L., Alonso-Zarza, A.M., Alvarez Sierra, M.A., Azanza, B., Calvo, J.P., Cañaveras, J.C., van Dam, J.A., Garcés, M., Krijgsman, W., van der Meulen, A.J., Morales, J., PeláezCampomanes, P., Pérez González, A., Sánchez Moral, S., Sancho, R., Sanz Rubio, E. 2000. El registro sedimentario y faunístico de las cuencas de Calatayud-Daroca y Teruel. Evolución paleoambiental y paleoclimática durante el Neógeno. Rev. Soc. Geol. España, vol. 13 (2), pp. 323-343.

Alonso, J.L., Pulgar, J.A., 2004. Estructura alpina de la Cordillera Cantábrica: generalidades. In: Vera, J.A. (Ed.), Geología de España. SGE-IGME, Madrid, pp. 332-343.

Alonso, J.L., Pulgar, J.A., García-Ramos, J.C., Barba, P., 1996. Tertiary basins and alpine tectonics in the Cantabrian mountains (NW Spain). In: Friend, P.F., Dabrio, C.J. (Eds.), Tertiary Basins of Spain. The Stratigraphic Record of Crustal Kinematics. Cambridge University Press, U.K., Cambridge, pp. 214-227.

Alonso-Zarza, A.M., Calvo, J.P., 2000. Palustrine sedimentation in an episodically subsiding basin: the Miocene of the northern Teruel Graben (Spain). Palaeogeography, Palaeoclimatology, Palaeoecology 160,1-21.

Alvaro, M., Capote, R., Vegas, R., 1978. Un modelo de evolución geotectónica para la Cadena Celtibérica. Acta Geológica Hispánica 14, 172-177.
Alves, T.M., Gawthorpe, R.L., Hunt, D.W., Monteiro, J.H., 2003. Post-Jurassic tectonosedimentary evolution of the Northern Lusitanian Basin (Western Iberian margin), Basin Research 15, 227-249.

Anadón, P., Moissenet, E., 1996. Neogene basins in the Eastern Iberian Range. In: Friend, P.F., Dabrio, C.J. (Eds.), Tertiary Basins of Spain. The Stratigraphic Record of Crustal Kinematics. Cambridge Univ. Press, Cambridge, pp. 68-76.

Anadón, P., Moissenet, E., Simón, J.L., 1990. The Neogene Grabens of the Eastern Iberian Chain (Eastern Spain). In: Agustí, J., Martinell, J. (Eds.), Iberian Neogene Basins. Field Guideboook. Paleont. i Evol. mem. Especial, vol. 2, pp. 97-130.

Andeweg, B., de Vicente, G., Cloetingh, S., Giner, J., Muñoz-Martín, A., 1999. Local stress fields and intraplate deformation of Iberia: variations in spatial and temporal interplay of regional stress sources. Tectonophysics 305, 153-164.

Antolín, B., Liesa, C., Casas, A.M., Gil, I., 2008. Geometry of fracturing linked to extension and basin formation in the Maestrazgo basin (Eastern Iberian Chain, Spain). Revista de la Sociedad Geológica de España 20 (3-4), 351-365.

Arboleya, M.L., Teixell, A., Charroud, M., Julivert, M., 2004. A structural transect through the High and Middle Atlas of Morocco. Journal of African Earth Sciences 39, 319-327.

Arlegui, L., Simón, J.L., 2001. Geometry and distribution of joint sets in a nonhomegeneous stress field: case study in the Ebro Basin (Spain). Journal of Structural Geology 32, 297-313.

Arlegui, L.E., Soriano, A., 2003. An example of a comparison between Thematic Mapper and radar images in the central Ebro basin. International Journal of Remote Sensing 24 (3), 457-474

Arthaud, F., Matte, P., 1975. Les décrochements tardi-herciniens du Sud-Ouest de l'Europe: geómetrie et essai de reconstruction des conditions de la deformation. Tectonophysics 25, 139-171.

Babault, J., Van Den Driessche, J., Bonnet, S., Castelltort, S., Crave, A., 2005. Origin of the highly elevated Pyrenean peneplain. Tectonics 24, TC2010. doi:10.1029/ 2004TC001697.

Babault, J., Loget, N., Van Den Driessche, J.V.D., Castelltort, S., Bonnet, S., Davy, P., 2006 Did the Ebro basin connect to the Mediterranean before the Messinian salinity crisis? Geomorphology 81, 155-165.

Babault, J., Bonnet, S., Van Den Driessche, J., Crave, A., 2007. High elevation of low-relief surfaces in mountain belts: does it equate to post-orogenic surface uplift? Terra Nova 19 (4), 272-277.

Balanyá, J.C., García-Dueñas, V., Azañón, J.M., Sánchez-Gómez, M., 1997. Alternating contractional and extensional events in the Alpujarride nappes of the Alboran Domain (Betics, Gibraltar Arc). Tectonics 16 (2), 226-238.

Benito-Calvo, A., Pérez-González, A., 2007. Erosion surfaces and Neogene landscape evolution in the NE Duero Basin (north-central Spain). Geomorphology 88, 226-241.

Birot, P., 1959. Esquisse morphologique des Monts Celtibériques orientaux. Bull. Comité Trav. Hist. et Scient., Sect. Géogr. pp. 101-130.

Blanco, M.J., Spakman, W., 1993. The P-wave velocity structures of the mantle below the Iberian Peninsula: evidence for subducted lithosphere below southern Spain. Tectonophysics 22, 13-34.

Bonow, J.M., Lidmar-Bergström, K., Japsen, P., 2006. Palaeosurfaces in central West Greenland as reference for identification of tectonic movements and estimation of erosion. Global and Planetary Change 50 (3-4), 161-183.

Borges, J.F., Fitas, A.J.S., Bezzeghoud, M., Teves-Costa, P., 2001. Seismotectonics of Portugal and its adjacent Atlantic area. Tectonophysics 331 (4), 373-387.

Cabral, J., 1989. An example of intraplate neotectonic activity, Vilariça Basin, northeast Portugal. Tectonics 8, 285-303.

Calvo, J.P., 2004. Rasgos comunes de las Cuencas cenozoicas. In: Geología de España (J.A: Vera ed.), SGE, IGME, Madrid, pp. 584-586.

Calvo, J.P., Daams, R., Morales, J., López-Martínez, N., Agustí, J., Anadón, P., Armenteros, I. Cabrera, L., Civis, J., Corrochano, A., Díaz-Molina, M., Elizaga, E., Hoyos, M., MartínSuárez, E., Martínez, J., Moissenet, E., Muñoz, A., Pérez-García, A., Pérez-González A., Portero, J.M., Robles, F., Santisteban, C., Torres, T., Van der Meulen, A.J., Vera, J.A., Mein, P., 1993. Up-to-date Spanish continental Neogene synthesis and paleoclimatic interpretation. Revista de la Sociedad Geológica de España 6 (3-4), 29-40.

Cañaveras, J.C., Calco, J.P., Hoyos, M., Ordoñez, S., 1996. Paleomorphologic features o fan intra-vallesian paleokarst, Tertiary Madrid Basin: significance of paleokarstic surface in continental basin analysis. In: Friend, P.F., Dabrio, C.J. (Eds.), Tertiary Basin of Spain. Cambridge Univ. Press, pp. 278-284.

Capote, R., Muñoz, J.A., Simón, J.L., Liesa, C.L., Arlegui, L.E., 2002. Alpine Tectonics I: the Alpine system north of the Betic Cordillera. In: Gibbons, W., Moreno, T. (Eds.), The Geology of Spain. . Geological Society, London, pp. 367-400.

Casas, A.M., Cortés-Gracia, A., 2002. Cenozoic landscape development in the central Iberian Chain (Spain). Geomorphology 44, 19-46.

Casas, A.M., Cortés, A.L., Maestro, A., Soriano, A., Riaguas, A., Bernal, J., 2000a. LINDENS: a program for lineament length and density analysis. Computers and Geosciences 26 (9-10), 1011-1022.

Casas, A.M., Cortés-Gracia, A.L., Maestro-González, A., 2000b. Intra-plate deformation and basin formation during the Tertiary within the Northern Iberian plate: origin and evolution of the Almazán Basin. Tectonics 19, 258-289.

Casas-Sainz, A.M., Faccenna, C., 2001. Tertiary compressional deformation of the Iberian plate. Terra Nova 13, 281-288.

Cloetingh, S., Burov, E., Beekman, F., Andeweg, B., Andriessen, P.A.M., García-Castellanos, D., de Vicente, G., Vegas, R., 2002. Lithospheric folding in Iberia. Tectonics 21 (5), 1041. 26 p. doi:10.1029/2001TC901031.

Cloetingh, S., Ziegler, P.A., Beekman, F., Andriessen, P.A.M., Hardebol, N., Van Wijk, J. Dèzes, P., 2006. Thermo-mechanical controls on Alpine deformation of NW Europe. In: Gee, D.G., Stephenson, R.A. (Eds.), European Lithosphere Dynamics. Memoirs, vol. 32. Geological Society of London, pp. 113-127.

Coney, P.J., Muñoz, J.A., McClay, K.R., Evenchick, C.A., 1996. Syntectonic burial and posttectonic exhumation of the southern Pyrenees foreland fold-thrust belt. Journal of the Geological Society, London 153, 9-16. 
Cortés, A.L., 1999. Evolución tectónica reciente de la Cordillera Ibérica, Cuenca del Ebro y Pirineo centro-occidental. Ph. D. Thesis, Univ. of Zaragoza, 409 pp.

Cortés, A.L., Maestro, A., Soriano, M.A., Casas, A.M., 1998. Lineaments and fracturing in the Neogene rocks of the Almazán basin (N Spain). Geological Magazine 135, 255-268.

Cortés, A., Soriano, A., Maestro, A., Casas, A.M., 2003. The role of tectonic inheritance in the development of recent fracture systems, Duero Basin, Spain. International Journal of Remote Sensing 24 (22), 4325-4345.

Crespo Blanc, A., Orozco, M., Garcia-Dueñas, V., 1994. Extension versus compression during the Miocene tectonic evolution of the Betic chain. Late folding of normal fault system. Tectonics $13,78-88$.

De Bruijne, C.H., Andriessen, P., 2002. Far field effects of alpine plate tectonism in the Iberian microplate recorded by fault-related denudation in the Spanish Central System. Tectonophysics 349, 161-184.

De Brum Ferreira, A., 1991. Neotectonics in Northern Portugal. A geomorphological approach. Z. Geomorph. N.F. Suppl.-Bd., vol. 82, pp. 73-85.

De Vicente, G. (ed.), 2004. Estructura alpina del antepaís ibérico, in: Geología de España, J.A. Vera ed. S.G.E.-I.G.M.E.

De Vicente, G., Vegas, R., 2009-this issue. Topography controlled by large scale distributed deformation along the western Africa-Eurasia limit: Tectonic constrains. Tectonophysics.

De Vicente, G., Giner, J.L., Muñoz Martín, A., González Casado, J.M., Lindo, R., 1996 Determination of the present-day stress tensor and the neotectonic interval in the Spanish Central System and the Madrid Basin, Central Spain. Tectonophysics 266 405-424.

De Vicente, G., Vegas, R., Muñoz Martín, A., Silva, P.G., Andriessen, P., Cloetingh, S González Casado, J.M., Van Wees, J.D., Álvarez, J., Carbó, A., Olaiz, A., 2007. Cenozoic thick-skinned deformation and topography evolution of the Spanish Central System. Global and Planetary Change 58, 335-381.

De Vicente, G., Cloetingh, S., Muñoz-Martín, A., Olaiz, A., Stich, D., Vegas, R., GalindoZaldívar, J., Fernández-Lozano, J.D., 2008. Inversion of moment tensor focal mechanisms for active stresses around the Microcontinent Iberia: Tectonic implications. Tectonics 27. doi:10.1029/2006TC0022093.

Dewey, J.F., Helman, M.L., Turco, E., Hutton, D.H.W., Knott, S., 1989. In: Coward, M.P. Dietrich, D. (Eds.), Kinematics of the Western Mediterranean. Alpine Tectonic, 45, pp. 265-283.

Dhont, D., Chorowicz, J., Yürür, t., Froger, J.-L., Köse, O., Gündogdu, N., 1998. Emplacement of volcanic vents and geodynamics of Central Anatolia, Turkey. Journal of Volcanology and Geothermal Research 85, 33-54.

El Harfi, A., Guiraud, M., Lang, J., 2006. Deep-rooted "thick skinned" model for the High Atlas Mountains (Morocco). Implications for the structural inheritance of the southern Tethys passive margin. Journal of Structural Geology 28 (11), 1958-1976.

England, P., Molnar, P., 1990. Surface uplift, uplift of rocks, and exhumation of rocks. Geology 18, 1173-1177.

Fernàndez, M., Marzán, I., Correia, A., Ramalho, E., 1998. Heat flow, heat production, and lithospheric thermal regime in the Iberian Peninsula. Tectonophysics 291, 29-53.

Ferreira-Soares, A., Fonseca-Marques, J., Rocha, R.E.B., Proença e Cunha, P., Pinto-Duarte, L.V., Sequeira, A.J.D., Bernardo de Sousa, M., Gama-Pereira, L.C., Gomes, E., Pereira, E., Rola dos Santos, J., 2005. Carta Geológica de Portugal, Folha 19-D, Coimbra-Lousà 1:50000, Instituto de Engenharia, Tecnología e Inovaçao.

García-Castellanos, D., Vergés, J., Gaspar-Escribano, J., Cloetingh, S., 2003. Interplay between tectonics, climate, and fluvial transport during the Cenozoic evolution of the Ebro Basin (NE Iberia). Journal of Geophysical Research 108 (B7), 2347 p. doi:10.1029/2002JB002073.

García-Mondéjar, J., Agirrezabala, L.M., Aranburu, A., Fernández-Mendiola, P.A., Gómez Pérez, I., López-Horgue, M.A., Rosales, I., 1996. The Aptian-Albian tectonic pattern of the Basque-Cantabrian Basin (Northern Spain). Geological Journal 31, 13-45.

García-Quintana, A., García-Hidalgo, J.F., Martin-Duque, J.F., Pedraza, J., GonzálezMartin, J.A., 2004. Geological factors on the Guadalajara Landscapes (Central Spain) and their relevance to landscape studies. Lanscape and Urban Planning 69, 417-435.

Gaspar-Escribano, J.M., García-Castellanos, D., Roca, E., Cloetingh, S., 2004. Cenozoic vertical motions of the Catalan Coastal Ranges (NE Span): the role of tectonics, isostasy, and river transport. Tectonics 23, TC1004. doi:10.1029/2003TC001511.

Giner, J.L., 1996. Análisis neotectónico y sismotectónico en el sector centro-oriental de la cuenca del Tajo. PhD. Thesis Univ. Complutense de Madrid, Spain.

Gladfelter, B.G., 1971. Meseta and Campiña landforms in Central Spain. A Geomorphology of the Alto Henares Basin. Dept. Geogr. Res. Paper, vol. 130. Univ. of Chicago. 204 p.

González, A., Guimerà, J., Luzón, A., 1998. Edad Oligoceno superior-Mioceno inferior para las superficies de erosión conservadas en el flanco SW de la cubeta de Bordón (Provincia de Teruel, España). Geogaceta 24, 155-158.

Gonzalo Moreno, A.N., 1979. La Rioja. Análisis de Geomorfología estructural. Instituto de Estudios Riojanos. 508 p.

Gracia, F.J., Gutiérrez, F., Gutiérrez, M., 2001. Origin and evolution of the Gallocanta polje (Iberian Range, NE Spain). Zeitschrift für Geomorphologie 46 (2), 245-262.

Gracia, F.J., Gutiérrez, F., Gutiérrez, M., 2002. The Jiloca karst polje-tectonic graben (Iberian Range, NE Spain). Geomorphology 52, 215-231.

Gràcia, E., Pallas, R., Soto, J.I., Comas, M., Moreno, X., Masana, E., Santanach, P., Diez, S. García, M., Dañobeitia, J., 2006. Active faulting offshore SE Spain (Alboran Sea): implications for earthquake hazard assessment in the Southern Iberian Margin. Earth and Planetary Science Letters 24 (3-4), 734-749.

Gracia Prieto, F.J., Nozal Martín, F., Pineda Velasco, A., Wouter de Vries, P.F., 1990 Superficies de erosión neógenas y neotectónica en el borde NE de la Cuenca de Duero. Geogaceta 7, 38-40.

Guimerà, J., Alvaro, M., 1990. Structure et évolution de la compression alpine dans la Chaîne Ibérique et la Chaîne Côtière Catalane. Bulletin de la Société Géologique de France 8 (6), 339-348.
Guimerà, J., González, A., 1998. El relieve de la Cadena Ibérica como un producto de la compresión alpina. Geogaceta 24, 163-166.

Guimerà, J., Salas, R., Vergés, J., Casas, A., 1996. Extensión mesozoica e inversión compresiva terciaria en la Cadena Ibérica: aportaciones a partir del análisis de un perfil gravimétrico. Geogaceta 20 (7), 1691-1694.

Gutiérrez, F., Gracia, J., Gutiérrez, M., 1996. Consideraciones sobre el final del relleno endorreico de las fosas de Calatayud y Teruel y su paso al exorreísmo. Implicaciones morfo-estratigráficas y estructurales. IV Reunión Nacional de Geomorfología, S.E.G., O Castro (A Coruña), Spain, pp. 23-43.

Gutiérrez, F., Gutiérrez, M., Gracia, F.J., McCalpin, J.P., Lucha, P., Guerrero, J., 2008. PlioQuaternary extensional seismotectonics and drainage network development in the central sector of the Iberian Range (NE Spain). Geomorphology 102 (1), 21-42.

Gutiérrez Elorza, M., Gracia, F.J., 1997. Environmental interpretation and evolution of the Tertiary erosion surfaces in the Iberian Range (Spain). In: Widdowson, M. (Ed.), Palaeosurfaces: Recognition, Reconstruction and Palaeoenvironmental Interpretation. Geol. Soc. Spec. Publication, London, vol. 120, pp. 147-158.

Hancock, P.L., 1985. Brittle microtectonics: principles and practice. Journal of Structural Geology 7, 437-457.

Herraiz, M., De Vicente, G., Lindo Ñaupari, R., Giner, J., Simón, J.L., González Casado, J.M., Vadillo, O., Rodríguez Pascua, M.A., Cicuéndez, J.I., Casas, A., Cabañas, L., Rincón, P., Cortés, A.L., Ramírez, M., Lucini, M., 2000. The recent (upper Miocene to Quaternary) and present tectonic stress distributions in the Iberian Peninsula. Tectonics 19, 762-786.

Herrero, A., Alonso Gavilán, G., Colmenero, J.R., 2004. Estratigrafía del subsuelo en el sector noroeste de la cuenca del Duero (Provincia de León). Revista de la Sociedad Geológica de España 17 (3-4), 199-216.

Jaspeen, P., Bonow, J.M., Green, P.F., Chalmers, J.A., Lidmar-Bergström, K., 2006. Elevated passive continental margins: long-term highs or Neogene uplifts? New evidence from West Greenland. Earth and Planetary Science Letters 248, 315-324.

Jiménez, E., Corrochano, A., Alonso-Gavilán, G., 1983. El Paleógeno de la Cuenca del Duero. Libro Jubilar J. M. Ríos. Geología de España, vol. 2. IGME, (Madrid), pp. 489-494.

Juez-Larré, J., Andriessen, P.A.M., 2002. Post Late Paleozoic tectonism in the southern Catalan Coastal Ranges (NE Spain), assessed by apatite fission track analysis. Tectonophysics 349, 113-129.

Junco Aguado, F., 1983. Cuenca occidental del Tajo. Libro Jubilar J. M. Ríos. Geología de España, vol. 2. IGME, (Madrid), pp. 553-558.

Junco Aguado, F., Calvo Sorando, J.P., 1983. Cuenca de Madrid. Libro Jubilar J.M. Ríos. Geología de España, vol. 2. IGME, pp. 534-543 (Madrid).

Kooi, H., Beaumont, C., 1994. Escarpment evolution on high-elevation rifted margins: insights derived from a surface processes model that combines diffusion, advection and reaction. Journal of Geophysical Research 99 (B6), 12191-12209.

Kullberg, J.C., 2000. Evolução tectónica mesozóica da Bacia Lusitaniana, PhD thesis, 285 p., Univ. Nova Lisboa.

Lanaja, J.M., 1987. Contribución de la exploración petrolífera al conocimiento de la Geología de España. Instituto Geológico y Minero de España, Madrid. 465 p.

Lewis, C.J., Vergés, J., Marzo, M., 2000. High mountains in a zone of extended crust: Insights into the Neogene and Quaternary topographic development of northeastern Iberia. Tectonics 19, 86-102.

Lidmar-Bergström, K., 1988. Denudation surfaces of a shield area in south Sweden. Geografiska Annaler 70A, 315-324.

Lidmar-Bergström, K., 1996. Long-term morphotectonic evolution in Sweden. Geomorphology 16, 33-59.

Liesa, C.L., Soria, A.R., Meléndez, A., 2000. Estructura extensiva cretácica e inversión terciaria del margen noroccidental de la subcuenca de Las Parras (Cordillera Ibérica, España). Geotemas 1 (2), 231-234.

Liesa, C.L., Soria, A.R., Meléndez, N., Meléndez, A., 2006. Extensional fault control on the sedimentation patterns in a continental rift basin: El Castellar Formation, Galve sub-basin, Spain. Journal of the Geologica Society, London 163, 487-498.

Martínez-Peña, M.B., Casas-Sainz, A.M., 2003. Cretaceous-Tertiary tectonic inversion of the Cotiella Basin (Southern Pyrenees, Spain). International Journal of Earth Sciences 92, 99-113.

Martín-Serrano, A., 1991. La definición y el encajamiento de la red fluvial actual sobre el Macizo Hespérico en el marco de su geodinámica alpina. Revista de la Sociedad Geológica de España 4 (3-4), 337-351.

Masana, E., 1994. Neotectonic features of the Catalan Coastal Range, Northeast Spain. Acta Geològica Hispànica 29 (2-4), 107-122.

McClay, K., Muñoz, J.A., García-Senz, J., 2004. Extensional salt tectonics in a contractional orogen; a newly identified tectonic event in the Spanish Pyrenees. Geology 32 (9), 737-740.

Mediavilla, R.M., Dabrio, C.J., Martín-Serrano, A., Santisteban, J.I., 1996. Lacustrine Neogene systems of the Duero basin: evolution and controls. In: Friend, P.F. Dabrio, C.J. (Eds.), Tertiary basins of Spain: the stratigraphic record of crustal kinematics. Cambridge Univ. Press, Cambridge, pp. 228-236.

Mezcua, J., Gil, A., Benarroch, R., 1996. Estudio gravimétrico de la Península Ibérica y Baleares, Inst. Geogr. Nac., Madrid, Spain, 2 maps.

Moissenet, E., 1985. Les aplanissements partiels sur les calcaires de la Chaîne Ibérique orientale. Cônes rocheux. Mémoires et Documents de Géographie, Editions du C.N.R.S., Paris.

Moissenet, E., 1989. Les fossés néogenes de la Chaîne ibérique: leur évolution dans le temps. Bulletin de la Société Géologique de France 5, 919-926 (ser. 8)

Montenat, C., Guéry, F., Jamet, M., Berthou, P.-Y., 1988. Mesozoic evolution of the Lusitanian basin: comparison with the adjacent margin. In: Boillot, G., et al. (Ed.), Proceedings of the Ocean Drilling Program. Scientific Results, vol. 103, pp. 757-775.

Morel, J.-L., Zouine, E.-M., Andrieux, J., Faure-Muret, A., 2000. Déformation néogènes et quaternaries de la bordure nord haut atlasique (Maroc): rôle du socle et conséquences structurales. Journal of African Earth Sciences 30 (1), 119-131. 
Muñoz, J.A., 1992. Evolution of a continental collision belt: ECORS-Pyrenees crustal balanced cross-section. In: McClay, K.R. (Ed.), Thrust tectonics. Chapman \& Hall, pp. 235-246.

Muñoz-Jiménez, A., Casas-Sainz, A.M., 1998. The Rioja Trough (N Spain): tectosedimentary evolution of a symmetric foreland basin. Basin Research 9, 65-85.

Muñoz-Martín, A., Cloetingh, S., De Vicente, G., Andeweg, B., 1998. Finite-element modelling of Tertiary paleostress fields in the eastern part of the Tajo Basin. Tectonophysics 300, 47-62.

Peizhen, Z., Molnar, P., Downs, W.R., 2001. Increased sedimentation rates and grain sizes $2-4 \mathrm{Myr}$ ago due to the influence of climate change on erosion rates. Nature 410 , 891-897.

Pérez-Rivarés, F.J., Garcés, M., Arenas, C., Pardo, G., 2002. Magnetocronología de la sucesión miocena de la Sierra de Alcubierre (sector central de la Cuenca del Ebro). Revista Sociedad Geológica de España 15, 210-225.

Pérez-Rivarés, F.J., Garcés, M., Arenas, C., Pardo, G., 2004. Magnetostratigraphy of the Miocene continental deposits of the Montes de Castejón (central Ebro basin, Spain): geochronological and paleoenvironmental implications. Geologica Acta 2 (3), 221-234.

Peulvast, J.P., Sales, C., 2004. Stepped surfaces and palaeolandforms in the northern Brazilian «Nordeste»: constraints on models of morphotectonic evolution. Geomorphology 62, 89-122.

Pinheiro, L.M., Wilson, R.C.L., Reis, R.P., Whitmarsh, R.B., Ribeiro, A., 1996. The Western Iberia margin: a geophysical and geological overview. In: Whitmarsh, R.B., et al. (Ed.) Proceedings of the Ocean Drilling Program. Scientific Results, vol. 149, pp. 3-23.

Proença Cunha, P., Antunes Martins, A., Daveau, S., Friend, P.F., 2005. Tectonic control of the Tejo river fluvial incisión during the late Cenozoic, in Ródao-central Portugal (Atlantic Iberian border). Geomorphology 64, 271-298.

Puigdefàbregas, C., 1975. La sedimentación molásica en la Cuenca de Jaca. Monografías del Instituto de Estudios Pirenaicos, vol. 104. Jaca (Spain), 187 p.

Pujalte, V., 1982. La evolución paleogeográfica de la cuenca "Wealdiense" de Cantabria. Cuadernos Geología Ibérica, vol. 8, pp. 65-83.

Pujalte, V., 1989. Ensayo de correlación de las sucesiones del Oxfordiense-Barremiense de la Región Vasco-Cantábrica basado en macrosecuencias deposicionales: implicaciones paleogeográficas. Cuadernos Geología Ibérica 13, 199-215.

Riba, O., Reguant, S., Villena, J., 1983. Ensayo de síntesis estratigráfica y evolutiva de la cuenca terciaria del Ebro. Libro Jubilar J. M. Ríos. Geología de España, vol. 2. IGME, pp. 131-159 (Madrid).

Ribeiro, A., Baptista, Cabral, J., Matias, L., 1996. Tectonic stress pattern in Portugal mainland and the adjacent Atlantic region (West Iberia). Tectonics 15, 641-659.

Roca, E., 1994. La evolución geodinámica de la Cuenca Catalano-Balear y áreas adyacentes desde el Mesozoico hasta la actualidad. Acta Geològica Hispànica 29 (1), 3-25.

Roca, E., Guimerà, J., 1992. The Neogene structure of the eastern Iberian margin structural constraints on the crustal evolution of the Valencia trough (western Mediterranean). Tectonophysics 203, 203-218.

Rodríguez Vidal, J., 1983. Geomorfología de las Sierras Exteriores oscenses y su piedemonte. Doctoral Thesis. University of Zaragoza. Pub. Instituto de Estudios Altoaragoneses, Huesca, 493 pp.

Rosenbaum, G., Lister, G.S., Duboz, C., 2002. Relative motions of Africa, Iberia and Europe during Alpine orogeny. Tectonophysics 359, 117-129.

Sàbat, F., Roca, E., Muñoz, J.A., Vergés, J., Santanach, P., Massana, E., Sans, M., Estévez, A. Santisteban, C., 1995. Role of extension and compression in the evolution of the eastern margin of Iberia: the ESCIValencia trough seismic profile. Revista de la Sociedad Geológica de España, vol. 8, pp. 303-543.

Sabins Jr., F.F., 1987. Remote Sensing. Principles and Interpretation. W.H. Freeman and Co., New York. 449 pp.

Salas, R., Casas, A., 1993. Mesozoic extensional tectonics, stratigraphy and crustal evolution during the Alpine cycle of the eastern Iberian basin. Tectonophysics 228, 33-55

Sancho, C., Peña, J.L., Lewis, C., McDonald, E., Rhodes, E., 2004. Registros fluviales y glaciares cuaternarios en las cuencas de los ríos Cinca y Gállego (Pirineos y depresión del Ebro), Geo-Guías 1. Itinerarios geológicos por Aragón. Sociedad Geológica de España, pp. 181-205.

Santisteban, J.I., Schulte, L., 2007. Fluvial networks of the Iberian Peninsula: a chronological framework. Quaternary Science Reviews 26, 2738-2757.

Santisteban, J.I., Mediavilla, R., Martín-Serrano, A., Dabrio, C.J., 1996. The Duero Basin: a general overview. In: Friend, P.F., Dabrio, C.J. (Eds.), Tertiary basins of Spain: the stratigraphic record of crustal kinematics. Cambridge Univ. Press, Cambridge, pp. 183-187.

Sanz de Galdeano, C.M., 1996. Tertiary tectonic framework of the Iberian Peninsula. In: Friend, P.F., Dabrio, C.J. (Eds.), Tertiary basins of Spain: the stratigraphic record of crustal kinematics. Cambridge University Press, Cambridge, pp. 9-14.

Sébrier, M., Siame, L., Zouine, E.-L., Winter, T., Missenard, Y., Leturmy, P., 2006. Active tectonics in the Moroccan High Atlas. C.R. Geoscience 338, 65-79.

Simón, J.L., Arlegui, L.E., Liesa, C.L., Maestro, A., 1999. Stress perturbations registered by jointing near strike-slip, normal, and reverse faults: examples from the Ebro Basin, Spain. Journal of Geophysical Research B7 (104), 15141-15153.
Simón Gómez, J.L., 1983. Tectónica y neotectónica del sistema de fosas de Teruel. Teruel 69, 21-97.

Simón Gómez, J.L., 1984. Compresión y distensión alpinas en la Cadena Ibérica Oriental. Ph. D. Thesis, Univ. of Zaragoza. Pub. Instituto de Estudios Turolenses, Teruel, 269 p.

Simón Gómez, J.L., 1986. Analysis of a gradual change in stress regime (example from the eastern Iberian Chain, Spain). Tectonophysics 124, 37-53.

Simón Gómez, J.L., 1989. Late Cenozoic stress field and fracturing in the Iberian Chain and Ebro Basin (Spain). Journal of Structural Geology 11 (3), 285-294.

Solé Sabarís, L., 1978. La Meseta. In: De Terán, M. (Ed.), Geografía de España. Ariel Madrid, pp. 42-62.

Solé Sabarís, L., 1983. Morfología general de la Península Ibérica. In: Comba, J.A. (Ed.), Geología de España. Libro Jubilar J.M. Ríos, 2. IGME, Madrid, pp. 589-605.

Sopeña, A., Virgili, C., Arche, A., Ramos, A., Hernando, S., 1983. El Triásico. In: Comba, J.A (Ed.), Geología de España.Libro Jubilar J.M. Ríos, vol. II. Instituto Geológico y Minero de España, pp. 47-63.

Soto, R., Storti, F., Casas-Sainz, A.M., 2006. Impact of backstop thickness lateral variations on the tectonic architecture of orogens: insights from sandbox analogue modelling and application to the Pyrenees. Tectonics 25. doi:10.1029/2004TC001693.

Soto, R., Villalaín, J.J., Casas, A.M., 2008. Remagnetizations as a tool to analyse the tectonic history of inverted sedimentary basins: a case study from the BasqueCantabrian basin (North Spain). Tectonics 27, TC1017. doi:10.1029/2007TC002208.

Souriau, A., Pauchet, H., 1998. A new synthesis of Pyrenean seismicity and its tectonic implications. Tectonophysics 290, 221-244.

Stich, D., Batlló, J., Macià, R., Teves-Costa, P., Morales, J., 2005. Moment tensor inversion with single-component historical seismograms: the 1909 Benavente (Portugal) and Lambesc (France) earthquakes. Geophysical Journal International 162, 850-858.

Stich, D.M., Serpelloni, E., Mancilla, F., Morales, J., 2006. Kinematics of the IberiaMaghreb plate contact from seismic moment tensors and GPS observations. Tectonophysics 426, 295-317.

Teixell, A., 1998. Crustal structure and orogenic material budget in the west centra Pyrenees. Tectonics 17 (3), 395-406.

Tejero, R., González-Casado, J.M., Gómez-Ortiz, D., Sánchez-Serrano, F., 2006. Insights into the "tectonic topography" of the present-day landscape of the central Iberian Peninsula (Spain). Geomorphology 76, 280-294.

Tesauro, M., Kaban, M., Cloetingh, S., 2007. A new crustal model as a basis for lithosphere modelling. 3rd International TOPO-Europe Workshop, Rome.

Tinker, J., de Wit, M., Brown, R., 2008. Mesozoic exhumation of the southern Cape, South Africa, quantified using apatite fission track thermochronology. Tectonophysics 455, 77-93.

Tokay, F., Altunel, E., 2005. Neotectonic activity of Eskisehir fault zone in vicinity of Inonu-Dodurga area. Mineral Research and Experimental Bulletin 130, 1-15.

Van Wees, J.D., Stephenson, R.A., 1995. Quantitative modelling of basin and rheological evolution of the Iberian Basin (Central Spain): implications for lithospheric dynamics of intraplate extension and inversion. Tectonophysics 252, 163-178.

Van Wees, J.D., Arche, A., Beijdorff, C.G., López-Gómez, J., Cloetingh, S.A.P.L., 1998 Temporal and spatial variations in tectonic subsidence in the Iberian Basin (eastern Spain): inferences from automated forward modelling of high-resolution stratigraphy (Permian- Mesozoic). Tectonophysics 300, 285-310.

Vázquez Hoehne, A., 1992. Superficies aplanadas en la paramera de Sigüenza. Anales de Geografía de la Universidad Complutense 11, 207-214.

Vegas, R., 1992. The Valencia trough and the origin of the western Mediterranean basins. Tectonophysics 203, 249-261.

Vergés, J., Fernàndez, M., 2006. Ranges and basins in the Iberian Peninsula: their contribution to the present topography. Memoirs, vol. 32. Geological Society, London, pp. 223-234.

Vidal Romaní, J.R., Yepes Temiño, J., Rodríguez Martínez-Conde, R., 1998. Evolución geomorfológico del macizo Hespérico peninsular. Estudio de un sector comprendido entre las provincias de Lugo y Ourense (Galicia, NW de España). Cadernos Laboratorio Xeoloxico de Laxe, vol. 23, pp. 165-199.

Villena, J., Pardo, G., Pérez, A., Muñoz Jiménez, A., González, A., 1996. Tertiary of the Iberian margin of the Ebro Basin: stratigraphic synthesis. In: Friend, P.F., Dabrio, C.J. (Eds.), Tertiary basins of Spain: the stratigraphic record of crustal kinematics. Cambridge University Press, Cambridge, pp. 77-82.

Zeyen, H.J., Banda, E., Gallart, J., Ansorge, E., 1985. A wide angle seismic reconnaissance survey of the crust and upper mantle in the Celtiberian Chain of eastern Spain. Earth and Planetary Science Letters 75, 393-402.

Ziegler, P.A., 1989. Evolution of the North Atlantic-an overview. In: Tankard, A.J. Balkwill, H.R. (Eds.), Extensional Tectonics and Stratigraphy of the North Atlantic Margins. Am. Assoc. Petrol. Geol. Mem., vol. 46, pp. 111-129.

Ziegler, P.A., 1990. Geological Atlas of Western and Central Europe. Shell Internat. Petrol. Mij. and Geol. Soc., London, 239 p. and 56 encl. 